\title{
1. OBJECTIVES, PRINCIPAL RESULTS, AND EXPLANATORY NOTES FOR LEG 73, SOUTH ATLANTIC OCEAN ${ }^{1}$
}

\author{
Kenneth J. Hsü, Geologisches Institut, Eidgenössische Technische Hochschule Zürich, CH-8092 Zürich, Switzerland \\ John LaBrecque, Lamont-Doherty Geological Observatory, Columbia University, Palisades, New York \\ and \\ Kenneth A. Pisciotto, Sohio Petroleum, San Francisco, California
}

\section{OBJECTIVES}

Leg 73 was the middle of five legs on South Atlantic paleoenvironments planned by the JOIDES Ocean Paleoenvironment (OP) Panel during the years from 1975 to 1980. The idea of drilling a transect of holes across the $30^{\circ} \mathrm{S}$ parallel was entertained soon after the drilling on Leg 3, during the first phase of the Deep Sea Drilling Project $(1968 / 69)$, when the surprising discovery was made that the middle Miocene sediments of the South Atlantic were largely marls and red clays. The deposition of the red clays was obviously related to the intense dissolution of calcite during the middle Miocene, when the calcite-compensation level was elevated. Since very few DSDP sites in the Atlantic were drilled in middle Miocene crust, on which the first sediment was laid down at a depth above the calcite compensation depth (CCD), we have few sample materials of that age for biostratigraphic or paleoceanographic studies. Therefore, at the start of the International Phase of Ocean Drilling (IPOD) in 1975, the first author proposed to the JOIDES Planning Committee that a transect of holes be drilled in the South Atlantic between Anomaly 5 and Anomaly 5C to sample potentially fossilrich middle Miocene sediments.

The objectives and tactical planning for a transect across the east flank of the Mid-Atlantic Ridge just north of $30^{\circ} \mathrm{S}$ were outlined by the OP Panel more fully to the Planning Committee in July of 1978. Drilling was proposed at three sites clustered near the ridge to obtain information on the middle Miocene CCD crisis; a second group of four sites, farther to the east, would be drilled to obtain information on the Eocene-Oligocene paleoceanographic revolution triggered by the onset of Antarctic glaciation. In addition, crustal sampling was planned at all sites to obtain datable material for a more precise determination of the seafloor spreading history in this region. Available magnetic and seismic data suggested the presence of one or more transform faults near $30^{\circ} \mathrm{S}$. To avoid any possible structural and stratigraphic complications related to these faults, it was proposed that site surveys be carried out along a traverse at about 24 to $25^{\circ} \mathrm{S}$, or, alternatively, 30 to $31^{\circ} \mathrm{S}$, between Marine Magnetic Anomalies 5 and 21, where the sedimentary cover was adequate.

${ }^{1}$ Hsü, K. J., LaBrecque, J. L., et al., Init. Repts. DSDP, 73: Washington (U.S.) Govt. Printing Office).
The drill proposal was eventually approved by the Planning Committee and scheduled for Leg 73. In 1979 the Marine Sciences Institute of the University of Texas at Galveston (R. Buffler, Chief Scientist) carried out the site survey for the proposed sites. At the last planning session of the OP Panel in Barbados in 1979, two broad aims of the cruise were spelled out, namely (1) to investigate the Cenozoic oceanography of the South Atlantic, particularly temperature gradients, circulation patterns, water chemistry, and biotic communities and their environmental adaptation and evolution, and (2) to develop the correlation between the reversal history of the Earth's magnetic field and biostratigraphic zonations. Precisely dated samples would be used to determine the timing and duration of specific paleoceanographic events during the last $70 \mathrm{~m} . y .$, particularly (1) the terminal Cretaceous event, (2) the middle Eocene events, (3) the terminal Eocene event, (4) the middle Oligocene events, (5) the middle Miocene dissolution events, (6) the terminal Miocene (Messinian) event, and (7) the Pliocene-Quaternary events. In addition, paleomagnetic samples were to provide field direction and intensity data for a study of Cenozoic geomagnetic field phenomena. To meet these objectives it was imperative that undisturbed cores be recovered. Thus, use of the hydraulic piston corer (HPC) was planned at all sites.

The suggestion that we extend the $30^{\circ} \mathrm{S}$ transect farther east to include a borehole for a study of the Cretaceous/Tertiary $(\mathrm{C} / \mathrm{T})$ boundary was first made by Isabella Premoli Silva in 1975. A site in the Angola Basin and two in the Cape Basin were planned, but they were all low priority targets, because previous DSDP cruises had failed to sample a continutous and undisturbed $\mathrm{C} / \mathrm{T}$ boundary. The discovery of geochemical anomalies (carbon and oxygen isotopes, iridium) at the boundary in 1978 and 1979 inspired us to review our priorities. After a piston core containing Paleocene sediments was taken in 1979 at the site in the Cape Basin at the foot of the Walvis Ridge, we began to entertain the idea that the $\mathrm{C} / \mathrm{T}$ contact might be sampled undisturbed by HPC there. Eventually, the investigation of the $\mathrm{C} / \mathrm{T}$ boundary event became an important goal of our cruise.

\section{CRUISE NARRATIVE}

The Glomar Challenger left Santos, Brazil on April 13, and arrived at Cape Town, South Africa, on June 1, 1980. During the 49 days at sea, we drilled 13 holes at six 
sites and recovered more than $1000 \mathrm{~m}$ of core (Fig. 1, Table 1).

The cruise started with 9 days under way. We reached Site 519 at $1139 \mathrm{hr}$. on April 22. The site was located on the shoulder of a submarine high. We started hydraulic piston coring at $0148 \mathrm{hr}$. on April 24, and the drilling proceeded smoothly through a section of pelagic oozes and turbidites. The cores were little disturbed, and the recovery rate was more than $90 \%$. After the HPC reached basement at $151.5 \mathrm{~m}$ sub-bottom, the drill string was recovered for a change to the rotary bit. Hole 519A was drilled primarily to obtain basalt samples.

The Neogene crust on both sides of the Mid-Atlantic Ridge constitutes the so-called rough basement. Block faulting resulted in a topography of local basins sur-

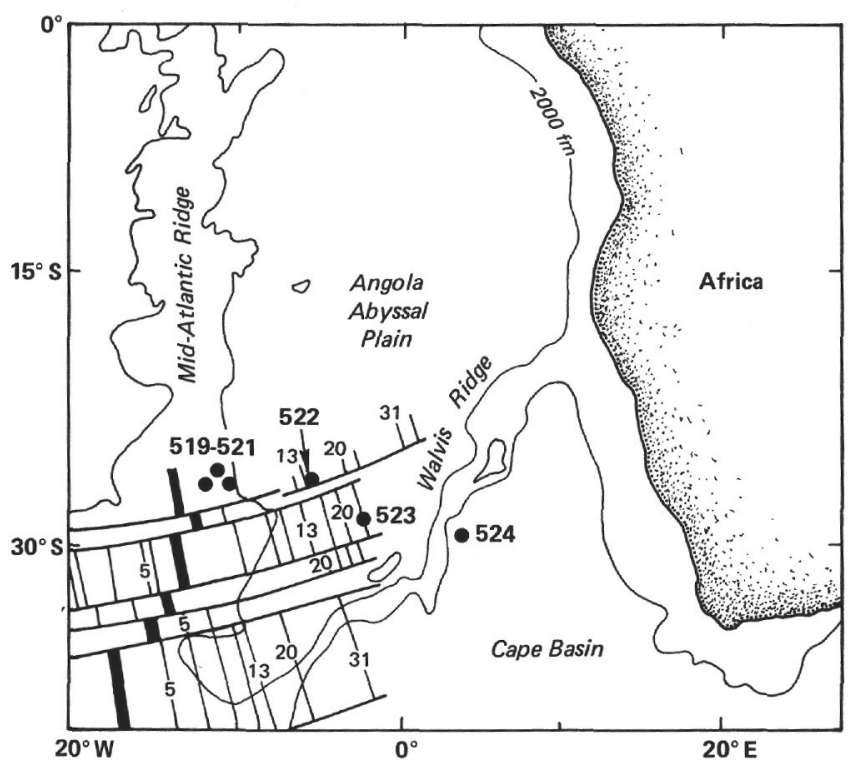

Figure 1. Location map showing positions of Leg 73 sites, marine magnetic anomalies, and the 2000 -fm bathymetric contour. rounded by submarine hills. We had noted during the planning sessions that the sedimentary cover on the hills was very thin and that the basin sequences, although thicker, might include many turbidite beds, which could render bio- and magnetostratigraphic interpretation difficult. Two alternative locations were chosen for each of the first three proposed sites, one on the hill and the other in the basin. Site 519 was a compromise; it was located on the slope, so that we cored both the ponded (Pliocene-Quaternary) and the draped (upper Miocene) facies. We were able to read the paleontologic and paleomagnetic signals of the ponded sediments despite resedimentation, but we suspected that there was a gap in the sedimentary record between the Pliocene and the Miocene at Site 519. Furthermore, the Leg 3 sites were all drilled on submarine highs, and the sampling there was biased. We decided, therefore, to drill Site 520 at a basinal location.

The next drill location was only $45 \mathrm{mi}$. to the northeast and was positioned on Anomaly 5B. The sediment thickness could not be precisely determined by seismic profiling because of interference by side echoes. We estimated a thickness of 250 to $300 \mathrm{~m}$. The procedure we followed was to use rotary coring to acquire samples of the deeper, more compacted sediments and then to raise the drill string to the mudline, release the drill bit, and sample the upper sediments in a different hole by HPC. We had several surprises during the operations. In addition to thick turbidites and slump deposits the basinal sequence included many layers of laminated diatomite beds, apparently laid down and preserved (from dissolution) in an anoxic environment. We were also surprised to find that the sediments were much thicker than we had expected; the basalt basement was reached at a depth of $450 \mathrm{~m}$. We had a third surprise when we drilled Hole 520A; the HPC was stopped at $20 \mathrm{~m}$ sub-bottom, apparently by a resedimented boulder (or gravelly layer). Since the sediments that would enable us to attain our primary objective (an upper Miocene magnetostra-

Table 1. Leg 73 coring summary.

\begin{tabular}{|c|c|c|c|c|c|c|c|c|c|c|c|c|}
\hline Hole & Longitude & Latitude & $\begin{array}{l}\text { Water } \\
\text { depth } \\
(\mathrm{m})\end{array}$ & $\begin{array}{l}\text { Hole } \\
\text { depth } \\
\text { (m) }\end{array}$ & $\begin{array}{c}\text { Number } \\
\text { of } \\
\text { cores }\end{array}$ & $\begin{array}{l}\text { Meters } \\
\text { cored }\end{array}$ & $\begin{array}{l}\text { Meters } \\
\text { recovered }\end{array}$ & $\begin{array}{c}\text { Recovery } \\
(\%)\end{array}$ & $\begin{array}{l}\text { Oldest } \\
\text { sample }\end{array}$ & $\begin{array}{l}\text { Magnetic } \\
\text { Epoch }\end{array}$ & $\begin{array}{l}\text { Seafloor } \\
\text { Anomaly }\end{array}$ & $\begin{array}{c}\text { Age } \\
\text { (m.y.) }\end{array}$ \\
\hline 519 & $26^{\circ} 08.20^{\prime} \mathrm{S}$ & $11^{\circ} 39.97^{\prime} \mathrm{W}$ & 3778.5 & 151.6 & 37 & 151.6 & 138.4 & 91.3 & upper Miocene & 10 & $5^{1} \mathrm{~N}$ & 10.10 \\
\hline $519 \mathrm{~A}$ & $26^{\circ} 08.20^{\prime} \mathrm{S}$ & $11^{\circ} 39.97^{\prime} \mathrm{W}$ & 3778.5 & 180.0 & 7 & 84.6 & 61.4 & 73.1 & Basalt & 10 & $5^{1} \mathrm{~N}$ & 10.1 \\
\hline 520 & $25^{\circ} 31.40^{\prime} \mathrm{S}$ & $11^{\circ} 11.14^{\prime} \mathrm{W}$ & 4217.0 & 458.5 & 31 & 246.5 & 69.4 & 28.1 & $\begin{array}{l}\text { middle Miocene- } \\
\text { Langhian }\end{array}$ & - & $5 B^{R}$ & 14.3 \\
\hline $520 \mathrm{~A}$ & $25^{\circ} 31.40^{\prime} \mathrm{S}$ & $11^{\circ} 11.14^{\prime} \mathrm{W}$ & 4217.0 & 18.5 & 1 & 2.4 & 2.4 & 100 & Quaternary & - & - & - \\
\hline 521 & $26^{\circ} 04.43^{\prime} \mathrm{S}$ & $10^{\circ} 15.87^{\prime} \mathrm{W}$ & 4141.0 & 84.0 & 21 & 84.0 & 75.4 & 89.7 & $\begin{array}{l}\text { middle Miocene- } \\
\text { Langhian }\end{array}$ & 16 & $5 \mathrm{C}^{\mathrm{N}}$ & 15.9 \\
\hline $521 \mathrm{~A}$ & $26^{\circ} 04.54^{\prime} \mathrm{S}$ & $10^{\circ} 15.59^{\prime} \mathrm{W}$ & 4141.6 & 71.1 & 17 & 71.1 & 64.3 & 90.4 & $\begin{array}{l}\text { middle Miocene- } \\
\text { Langhian }\end{array}$ & 16 & $5 \mathrm{C}^{\mathrm{N}}$ & 15.9 \\
\hline 522 & $26^{\circ} 06.84^{\prime} \mathrm{S}$ & $05^{\circ} 06.78^{\prime} \mathrm{W}$ & 4456.6 & 148.7 & 39 & 148.7 & 137.7 & 92 & upper Eocene & C-16-N & $16_{N}^{N}$ & 38.4 \\
\hline $522 \mathrm{~A}$ & $26^{\circ} 06.84^{\prime} \mathrm{S}$ & $05^{\circ} 06.78^{\prime} \mathrm{W}$ & 4456.6 & 156.0 & 31 & 106.0 & 97.9 & 89.9 & upper Eocene & $\mathrm{C}-16-\mathrm{N}$ & $16^{N}$ & 38.4 \\
\hline 522B & $26^{\circ} 06.84^{\prime} \mathrm{S}$ & $05^{\circ} 06.78^{\prime} \mathrm{W}$ & 4456.6 & 170.4 & 6 & 40.5 & 25.3 & 62.6 & upper Eocene & $\mathrm{C}-16-\mathrm{N}$ & $16^{\mathrm{N}}$ & 38.4 \\
\hline 523 & $28^{\circ} 33.13^{\prime} \mathrm{S}$ & $02^{\circ} 15.08^{\prime} \mathrm{W}$ & 4572.0 & 193.5 & 51 & 182.5 & 149.2 & 81.9 & middle Eocene & C-21-N & $20^{R 2}$ & 51.0 \\
\hline 524 & $29^{\circ} 29.05^{\prime} \mathrm{S}$ & $03^{\circ} 30.74^{\prime} \mathrm{E}$ & 4806.0 & 348.5 & 35 & 306.5 & 199.4 & 65 & $\begin{array}{l}\text { Upper } \\
\text { Cretaceous }\end{array}$ & C-31-R & ? & 71 \\
\hline $524 \mathrm{~A}$ & $29^{\circ} 29.05^{\prime} \mathrm{S}$ & $03^{\circ} 30.74^{\prime} \mathrm{E}$ & 4805.0 & 47.5 & 2 & 19.0 & 9.9 & 52 & $\begin{array}{l}\text { Upper } \\
\quad \text { Cretaceous }\end{array}$ & C-31-R & $?$ & - \\
\hline $524 \mathrm{~B}$ & $29^{\circ} 29.07^{\prime} \mathrm{S}$ & $03^{\circ} 30.74^{\prime} \mathrm{E}$ & 4804.5 & 29.5 & 7 & 29.5 & 20.7 & 7 & $\begin{array}{l}\text { Upper } \\
\text { Cretaceous }\end{array}$ & C-31-R & $?$ & - \\
\hline
\end{tabular}


tigraphy) lay more than $400 \mathrm{~m}$ sub-bottom and could not be reached by washing down a drill string without a drill bit, we decided to abandon the site. We would have moved to a hilltop site to acquire cores with the HPC if we had known then that the magnetostratigraphy of the upper middle Miocene would be so difficult to interpret. Instead, we hoped to achieve our objectives by drilling the next site on Anomaly 5C, which lay only $60 \mathrm{mi}$. to the southeast.

Hole 521 was spudded at $1814 \mathrm{hr}$. on May 2 in $4141 \mathrm{~m}$ of water, and the hydraulic piston coring progressed smoothly until basement was reached at $84 \mathrm{~m}$ sub-bottom. Because of the excellent recovery, the shipboard staff decided to invest some $20 \mathrm{hr}$. of ship time in obtaining a duplicate set of "cores by HPC. This decision proved to be wise, because shored-based study of Hole 521A cores helped us to interpret the magnetostratigraphy. Unfortunately, the upper middle Miocene sediments (NN6-NN10) here have been subjected to very intense dissolution, and we failed to obtain an unequivocal magnetostratigraphic calibration for the fossil zones of this age.

The preceding sites were chosen to permit the investigation of Neogene sediments. The next four proposed sites (SA IV, 4-7) were scheduled to investigate the $\mathrm{Pa}$ leogene. Site 522 was located $278 \mathrm{mi}$. east of Site 521 on Anomaly 16 . The hydraulic piston coring began at 0400 hr. May 7 and progressed smoothly down to a depth of $148.7 \mathrm{~m}$ sub-bottom, with excellent recovery of undisturbed cores. The sampled sequence proved to be a most reliable reference section for the Oligocene magnetostratigraphy. Realizing that no more drilling was scheduled for the South Atlantic in the near future, if at all, we decided to obtain a duplicate set of samples here. We had terminated the coring operations in Hole 522 a few meters above the basement to avoid the possibility of damaging the equipment. Hole 522A was spudded in at $1615 \mathrm{hr}$. May 9 and was washed down to $47 \mathrm{~m}$ sub-bottom, just above the Oligocene/Miocene boundary, before hydraulic piston coring was started. The basement was reached at $156 \mathrm{~m}$ sub-bottom, and the biostratigraphic age of the oldest sediment confirms that the seafloor spreading rate has been more or less linear since the late Eocene.

Site 523 was $210 \mathrm{mi}$. to the east of Site 522 . The site was approached in deteriorating weather and the pipe trip began after a 6.5-hr. weather delay. The hole was spudded in at $0615 \mathrm{hr}$. May 16, but a 12-ft. swell from the south-west persisted for the first day. Concurrent with the vessel motion caused by the swell, mechanical difficulties arose in the HPC. Consequently not all of the first 18 cores (down to a depth of $65 \mathrm{~m}$ ) were of the customarily excellent quality. Fortunately, the weather, the core quality, and the recovery percentage all improved after an Oligocene Braarudosphaera chalk was penetrated. The lower cores yielded samples that permitted a correlation of biostratigraphy, magnetostratigraphy, and seafloor anomalies from the middle Oligocene to the middle Eocene (Chron C-11 to Chron C-20; see Tauxe et al., this vol.).

At $1030 \mathrm{hr}$. on May 19 the HPC barrel broke while Core 48 was being taken. We did manage to wash down
$5 \mathrm{~m}$ past the broken barrel and to take three more cores. At that point we had penetrated almost $30 \mathrm{~m}$ of Chron C-20-R sediment, and the bottom of the borehole should have been only a few meters above the Anomaly 21 crust, but we began to have more operational difficulties. After the sand line sent down to retrieve the core barrel came back with the end broken, the drill string had to be tripped back to the rig floor.

We were now at a crossroad. We had only 6 days of on-site time left, and several alternatives were open to us. We could stay at Site 523 and obtain a duplicate set of undisturbed HPC cores for the first $65 \mathrm{~m}$ before washing down to sample the oldest sediments above the basement. We could proceed to the proposed Site SA IV-6 to drill the Anomaly 24 crust there in order to obtain samples of the lower Eocene and upper Paleocene sediments. Or we could proceed to Site SA II-6 in the Cape Basin to sample the Cretaceous/Tertiary boundary. After a long deliberation during a staff conference, the consensus was to gamble for the $\mathrm{C} / \mathrm{T}$ boundary, a prize too big to be ignored. We were not to regret our decision.

At Site 524 we made our most interesting find. The beginning of drilling was, however, marred by bad weather and human error, which resulted in the loss of a day and half. The vessel was on site and in auto (automatic positioning) at $2048 \mathrm{hr}$. on May 21, but the first core did not arrive on deck until $1302 \mathrm{hr}$. on May 23. We were to suffer another disappointment when a Paleocene chert layer was identified in Core 3, which was obtained by rotary drilling, at about $30 \mathrm{~m}$ sub-bottom; we had to accept the fact that we could not reach the $\mathrm{C} / \mathrm{T}$ contact by hydraulic piston coring. In fact, with the prevailing 50 to $70 \%$ recovery rate, we were not even certain that the contact would appear in the portion of the cores we recovered. Meanwhile, weather reports repeatedly warned us of the imminent invasion of storm fronts. However, we were lucky; the weather held, and we were able to obtain an undisturbed core by rotary drilling that included the $\mathrm{C} / \mathrm{T}$ boundary. After that event the operations were anticlimactic to everyone except the shipboard petrologist, who obtained an excellent suite of volcanic rocks from this hole.

Hole 524 terminated at $348.5 \mathrm{~m}$ sub-bottom in volcaniclastic sediments. Hole 524A was drilled with rotary bits to sample the sediments below the chert layer and above the continuously cored sequence of Hole 524. The operations were completed in about $4 \mathrm{hr}$. The drill bit was then dropped for conversion to the HPC. At 0843 hr. on May 27, Hole 524B was spudded in and seven hydraulic piston cores were obtained. Finally, drilling operations had to be terminated to meet the port call, and the vessel got under way for Cape Town at $0712 \mathrm{hr}$. on May 28 in the midst of a calm mirrorlike sea.

\section{PRINCIPAL RESULTS}

\section{Seafloor Magnetic Anomalies, Magnetostratigraphy, and Biostratigraphy}

The correlation of magnetostratigraphy and seafloor anomalies is based upon the polarity reversal patterns indicated by the natural remanent magnetization (NRM) 
in a sedimentary sequence and that manifested by the magnetic stripes on the seafloor. The correlation between these patterns is nearly perfect at almost all sites where clear magnetostratigraphic signals could be obtained. At Site 519, the seafloor anomaly has been identified as $5^{1}$, or a short normal epoch slightly older than Anomaly 5. The magnetostratigraphy of the sediment and the basalt confirms the correlation; the oldest sediment is reversely magnetized near the top of Chron 10 of Ryan and Dreyfus (see Tauxe et al. and Hsü et al., this vol.), and the chron (defined below) correlated to Anomaly $5^{1} \mathrm{~N}$ is identified in the NRM of the basalt. Site 520, which was drilled on Anomaly 5B, bottomed in sediments belonging to the nannofossil zone NN4. Site 521 was positioned over Anomaly 5C, and the oldest sediment there belongs to magnetostratigraphic Chron 16 , which correlates to Anomaly $5 \mathrm{C}$. The correlation of the magnetostratigraphy and the seafloor anomalies of the Paleogene sediments at other sites is so clear that we have decided to abandon the practice of establishing a dual nomenclature for magnetostratigraphic epochs. Instead, the magnetostratigraphic intervals, as recognized by the NRM of the sediments (and of the basalts), are referred to as chrons (Tauxe et al., this vol.) and are designated by the same number as the anomaly but distinguished from the latter by the prefix $\mathrm{C}$. LaBrecque and Tauxe have extended this nomenclature to the Neogene and Mesozoic reversal history as well. The $\mathrm{C}$ prefix for the proposed chron nomenclature distinguishes the new chron terminology from the Neogene terminology of Opdyke et al. (1974) and Theyer and Hammond (1974). The two Neogene terminologies are used interchangeably within the volume. See Figure 2 for a comparison of the two systems.

The magnetostratigraphic chrons have been assigned numerical ages by assuming a linear rate of seafloor spreading and by adopting a radiometric date for the beginning of the Cenozoic. Tauxe et al. (this vol.) came up with one set of ages on the basis of a 66.5 m.y. old Cenozoic. Hsu et al. (this vol.) suggested a set of revised magnetostratigraphic ages (shown below in parentheses after the date of Tauxe et al.) by adopting a $63.5 \mathrm{~m} . \mathrm{y}$. figure. A comparison of the numerical ages of magnetostratigraphically dated fossil zones with the radiometric ages of those zones provides a check on the validity of our assumptions. We have obtained magnetostratigraphic dates of 1.8 (1.7) m.y. for the Pleistocene/Pliocene boundary, 5.2 (5.0) m.y. for the Pliocene/Miocene boundary, 23.8 (22.7) m.y. for the Miocene/Oligocene boundary, 37.2 (35.6) m.y. for the Oligocene/Eocene boundary, and 59.0 (55.4) m.y. for the Eocene/Paleocene boundary. All except the last of those ages are either identical or very similar to those estimated by various authors on the basis of the radiometric dating of fossiliferous sediments. The agreement confirms the general validity of the assumption of a linear seafloor spreading rate during the Cenozoic. Two possible exceptions (intervals when the spreading rate may have deviated from linearity) are (1) the late Paleocene and early Eocene and (2) the middle Miocene. The radiometric ages of the former are significantly younger and those

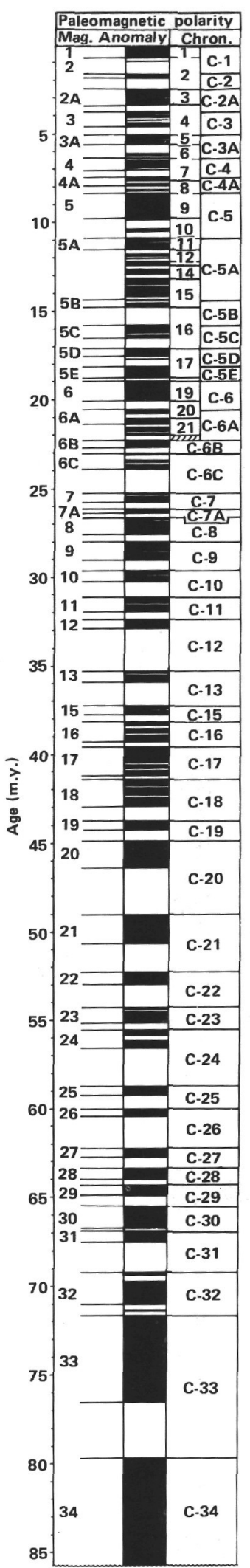

Figure 2. The definition of the chron nomenclature defined by LaBrecque and Tauxe with respect to the paleomagnetic time scale. The chronology of the time scale is that of LaBrecque et al. (1977); Larson and Hilde (1975); and Cande et al. (1978). The letter C is prefixed to the anomaly number in order to avoid confusion with pre-existing Neogene chron conventions. 
of the latter are significantly older than their magnetostratigraphic ages.

\section{Cenozoic Paleoceanography}

Precision stratigraphy permits an accurate timing of events. Paleontological, lithological, and stable-isotope data provide indications of paleoenvironmental changes.

The oxygen isotopes recorded a history of the oceantemperature changes in the South Atlantic during the Cenozoic. We confirmed the general cooling trend recognized by many previous authors, particularly the more rapid cooling during the late middle Eocene (45 (43)-42 (40) Ma), latest Eocene and earliest Oligocene (38 (36.5)-37 (35.5) Ma), early middle Miocene (14 (13.5)-13.5 (13) Ma), and middle and later Pliocene (3.5 (3.3)-3.2 (3) Ma and 2.7 (2.5)-2.4 (2.2) Ma).

Carbon shifts are commonly synchronous with oxygen shifts; they indicate changes in ocean chemistry.

Variations in the benthic fauna have been caused either by subsidence or by global changes in bottom temperature and/or circulation. We noted a significantly new (psychrospheric) benthic fauna during the Oligocene. We also found an increase in the percentage of the benthic species Nuttalides umbonifera in the sediment of a site as the seafloor there subsided to a depth below the Antarctic Bottom Water (AABW).

The calcite dissolution of pelagic sediments is manifested by the insoluble residue content of the sediments, the fragmentation of foraminiferal tests, the percentage of benthic tests, and other indicators. We recognized a number of sharp, episodic events, especially during the Pliocene and Pleistocene. The long-term trend, however, is for a depressed CCD during the Oligocene and the Pliocene-Quaternary and an elevated CCD during the Eocene and Miocene. The cause of the change in the CCD must have been very complex; there is no simple correlation between it and the extent of Antarctic glaciation or the flow intensity of the AABW. In fact, the high CCD during the Eocene and Miocene suggests that it is correlated with the higher sea levels that existed during those geologic epochs. We suspect that the global elevation of the CCD may have been related to reduced plankton productivity during those times.

The high fertility of plankton during the Oligocene and the Pliocene-Quaternary is indicated by the presence of the Oligocene Braarudosphaera chalks and of the Pliocene-Quaternary Ethmodiscus oozes. The occurrence of sediments consisting of the skeletons of only one fossil species required unusual fertility, as well as unusual circumstances that permitted their preservation. The distribution of the chalks and of the diatom oozes may indicate the flow path of ancient Benguela currents.

\section{Cretaceous/Tertiary Boundary}

The latest Mesozoic and earliest Tertiary sediments were thick enough at Site 524 to provide an amplified record of the environmental and biostratigraphic changes at the end of the Cretaceous. Paleontological and carbon-isotope data indicated that a high proportion of the ocean's planktonic organisms was eliminated at the end of the Cretaceous. An associated reduction in produc- tivity led to the partial transfer of dissolved carbon dioxide from the oceans to the atmosphere. This resulted in a large increase of the atmospheric $\mathrm{CO}_{2}$, indirectly causing a temperature rise, as revealed by our oxygenisotope data.

We also found an iridium anomaly in the clay at the $\mathrm{C} / \mathrm{T}$ boundary, which supports the hypothesis that a large body hit the Earth during that time. The impact may have caused a mass mortality "immediately" $\left(\sim 10^{3}\right.$ yr.), but our data indicate that the extinction took place during a 50,000-yr. period in environments that deteriorated directly or indirectly as a result of the impact. We postulate, therefore, that the catastrophic near extinction of the marine plankton was caused by environmental stress after a mass mortality in the surface waters of the ocean and that the large terrestrial reptiles became extinct because of thermal stress after the terminal Cretaceous catastrophe.

\section{Basement Petrology and Geochemistry}

Basalt pillow lava flows and sills were encountered in Holes 519A, 520, 522B, and 524. The major and trace element characteristics of the basalts from the three MidAtlantic-Ridge holes are similar to typical N (normal) MORB (mid-ocean-ridge basalt). However, the basalt suites from Hole 524, which was drilled into the south flank of the Walvis Ridge, include alkali as well as tholeiitic basalts. The alkali basalts have chemical characteristics similar to the lavas of the Tristan da Cunha group. Dietrich et al. (this vol.) suggest that the chain of volcanic centers extending from the Walvis Ridge to the Tristan da Cunha may have been produced when the African Plate moved over a large mantle plume.

\section{RESPONSIBILITIES FOR AUTHORSHIP}

The site chapters in this volume present the basic data and principal results for the holes drilled during Leg 73 . The authorship of the site chapters is collectively that of the shipboard scientific party, but ultimate responsibility lies with the Co-Chief Scientists, Kenneth Hsü and John LaBrecque. Each site chapter was compiled according to the standard format listed here (the names of the authors of each section are given in parentheses):

Data Sheet and Hole Summary (Hsü and LaBrecque)

Background and Objectives (Hsü and LaBrecque)

Sediment Lithology (Karpoff, McKenzie, Pisciotto, and Weissert)

Biostratigraphy Summary (Gombos, Percival, Poore, and Wright)

Calcareous Nannofossils (Percival)

Planktonic Foraminifers (Poore)

Diatoms (Gombos)

Benthic Foraminifers (Wright)

Dissolution (Wright)

Sedimentation Rates (Gombos, Percival, Poore, and Wright)

Igneous Rocks (Carman and Petersen)

Sediment Paleomagnetism (Tauxe and Tucker)

Basalt Paleomagnetism (Petersen)

Physical Properties (Schreiber)

Inorganic Geochemistry (Pisciotto) 
Correlation of Drilling Results with Geophysical Data (LaBrecque)

Summary and Conclusions (Hsü and LaBrecque [different parts])

\section{EXPLANATORY NOTES}

Standard procedures for both drilling operations and the preliminary analysis of the material recovered have been regularly amended and upgraded in the course of the deep-sea drilling effort. This chapter presents information that the reader may find helpful in understanding the terminology and conversions used in this volume. It is also intended to serve as a guide to sample selection for interested investigators. This information pertains only to the shipboard operations and analyses described in the site chapters. The reader is referred to individual scientific contributions for the details of the methods used by various investigators for the shorebased analysis of the Leg 73 data.

\section{Geophysical Equipment}

The seismic profiling system used on the Glomar Challenger during Leg 73 comprised both 5-cu.-in. and 40cu.-in. Bolt 600A airguns, Teledyne hydrophone streamers, modified Bolt amplifiers, two bandpass filters, and two Edo dry paper recorders operated at 5- and 10-s sweep rates and at variable filter settings. In addition to the seismic equipment, a Geometrics proton magnetometer was towed when the ship was under way.

The ship's track is satellite navigated, and the location of the drill sites is the mean of repeated $(\sim 10)$ satellite positions read while the ship was at the drill site and positioned over the acoustic beacon.

The depth of the water at the drill site is the depth measured with an Edo dry paper recorder. Sound velocity is assumed to be $1500 \mathrm{~m} / \mathrm{s}$ and corrected according to Mathews' (1939) tables. Further corrections are made for the depth of the hull-mounted sound transducer below the waterline of the vessel $(6 \mathrm{~m})$. When pipe lengths are measured from the derrick floor, a correction of 10 $\mathrm{m}$ is applied for the height of the floor above the waterline.

The depth at any level below the seafloor is the difference between the length of pipe needed to reach the seafloor and the length of pipe to the level in question. However, because of the presence of bumper-subs (a type of splined shock absorber in the bottom-hole assembly), the pipe can be telescoped about $3 \mathrm{~m}$ simply by increasing the weight on the bit. There is thus a small uncertainty in all of these depth measurements.

\section{Hydraulic Piston Corer}

Although some conventional rotary coring was done during Leg 73, the HPC was used extensively to recover undisturbed cores of soft sediment for precision stratigraphy. Figure 3 schematically illustrates the operational sequence of the HPC. To take a core the HPC is latched in and seated in the lowermost part of the drill pipe, flush with base of the drill bit. Seawater is then pumped at $350 \mathrm{gal} . / \mathrm{min}$. to actuate. Locking pins shear at 1700 psi, driving the core tube into the sediment. Once fired, the core tube is supposed to penetrate $4.4 \mathrm{~m}$ into the underlying sediment. The full extension of the HPC to this length is reflected on the rig floor by complete pressure bleedoff following the shot. After penetrating the sediment the HPC is pulled up $4.4 \mathrm{~m}$ to a position within the lowermost part of the drill string. The entire drill string is then raised to the point where a drill string tool joint appears at the level of the rig floor. The raised interval ranges from 0.0 to $9.5 \mathrm{~m}$ (the length of one joint of drill pipe). Thus, the length of the open hole beneath the drill bit can be as great as $13.9 \mathrm{~m}(9.5 \mathrm{~m}+4.4 \mathrm{~m})$. The drill string is then separated at the tool joint, and the inner core barrel (with the $4.4 \mathrm{~m}$ of sediment) is pulled to the rig floor on the sand line.

After the core is removed, the HPC inner core barrel is reloaded and returned to the base of the drill string. The special HPC drill bit then washes down through the sediment interval just previously cored. The base of the drill string is now at the desired level for the next HPC shot. The presence of an open hole below the drill string while the HPC inner core barrel is retrieved and reloaded and the fact that the drill string is washed down to the next position from which to fire the HPC explain why the upper parts of many of the hydraulic piston cores are contaminated with material previously cored and disturbed.

When the HPC is able to fully stroke out (4.4. $\mathrm{m}$ ) but recevers less than $4.4 \mathrm{~m}$ of core, the usual reason is that the core catcher has failed. The missing interval can be recovered, but the material is usually highly disturbed because it has been dropped. If the HPC does not fully stroke out (as indicated by no drop in water pressure), a continuous section can be recovered by measuring the amount of recovery in the core and then dropping the drill string to the level the nearest $0.5 \mathrm{~m}$ higher than the lowest point reached in the previous recovery. For instance, if Core 36 recovered $3.37 \mathrm{~m}$ of sediment, we would lower the drill string $3.0 \mathrm{~m}$ to start coring of Core 37. This approach ensures some overcoring of disturbed sediment but does not permit any section to be lost.

\section{Numbering of Sites, Holes, Cores, and Samples}

DSDP drill sites are numbered consecutively from the first site drilled by Glomar Challenger in 1968. Site numbers are slightly different from hole numbers. A site number refers to one or more holes drilled while the ship was positioned over one acoustic beacon. These holes may be located within a radius as great as $900 \mathrm{~m}$ from the beacon. Several holes may be drilled at a single site by pulling the drill pipe above the seafloor (out of the hole), moving the ship $100 \mathrm{~m}$ or more from the previous hole, and then beginning to drill another hole.

The first (or only) hole drilled at a site takes the site number. A letter suffix distinguishes each additional hole at the same site. For example, the first hole takes only the site number, the second takes the site number with suffix A, the third takes the site number with suffix $\mathrm{B}$, and so forth. It is important for sampling purposes to distinguish between the holes drilled at a site, because 


$\begin{array}{ll}\text { HPC is seated. } & \text { Pressure on traveling piston } \\ \text { Seawater is pumped } & \text { drives core barrel. Fluid above } \\ \text { at } 350 \text { gpm to } & \text { stationary piston is vented. } \\ \text { actuate. } & \text { Core barrel speed is approx. } \\ \end{array}$

actuate.

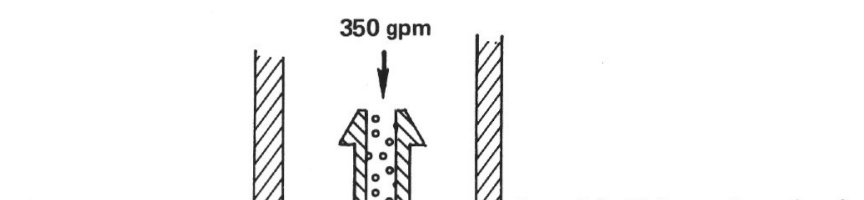

50 fet 36 feet

Stationary sealing top sub
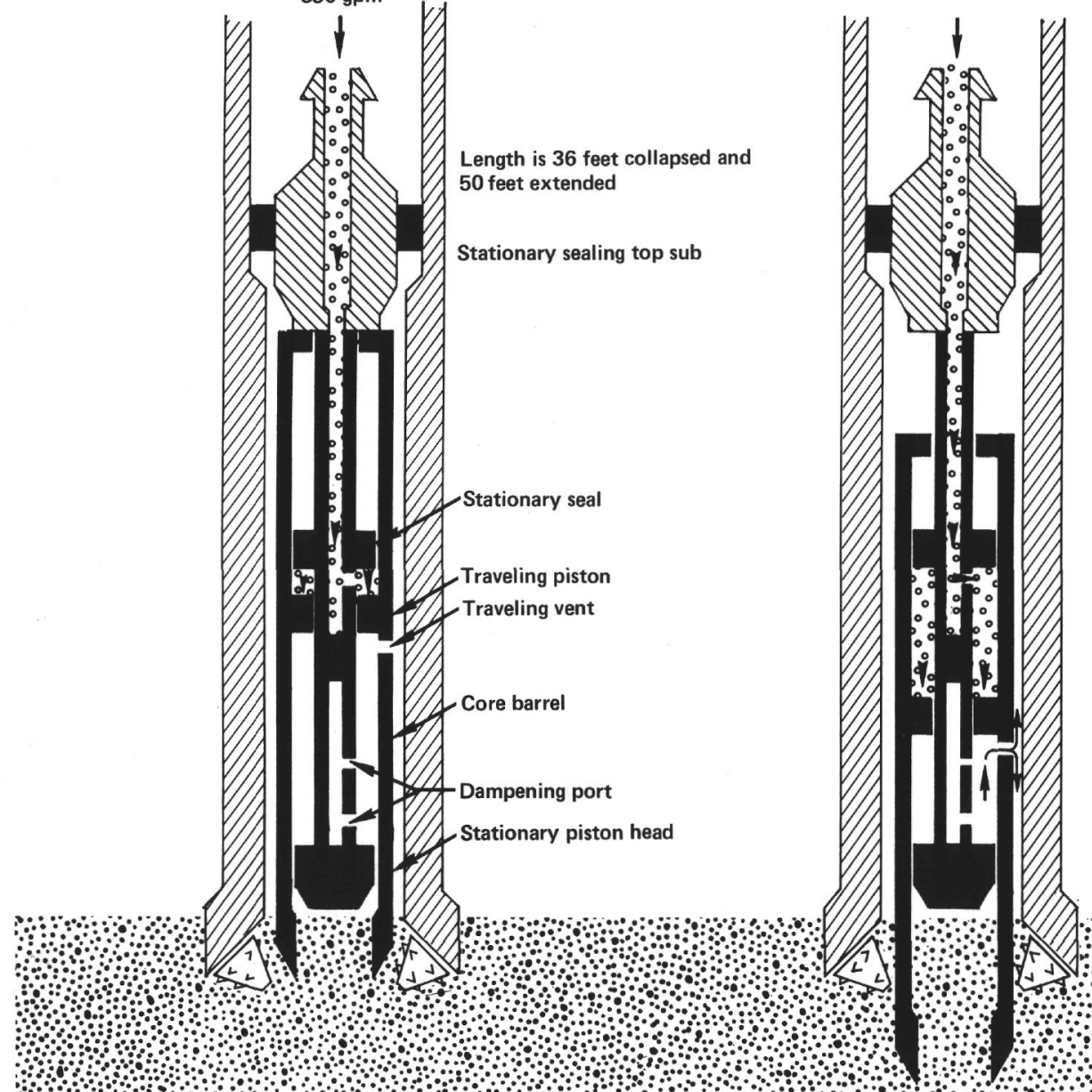

At the end of the stroke

dampening ports are uncovered and decelerate the core bar. 
recovered sediments or rocks from different holes usually do not come from equivalent positions in the stratigraphic column.

Cores are numbered consecutively from the top of each hole downward, even if they are separated by intervals that were not recovered. The depth interval specified for each core corresponds to the respective depths in meters below the seafloor at which the coring operation began and ended. Each interval is nominally the length of the core barrel (9.5 $\mathrm{m}$ for conventional, rotary-drilled cores, $4.45 \mathrm{~m}$ for hydraulic piston cores).

Full recovery for a single core is $9.28 \mathrm{~m}$ (conventional) or $4.25 \mathrm{~m}$ (HPC) of sediment or rock in a plastic liner $(6.6 \mathrm{~cm}$ inner diameter) plus about $0.2 \mathrm{~m}$ of material in the core catcher, which is not in the liner. The core catch- er is the device at the bottom of the core barrel that prevents the cored sample from sliding out when the barrel is being retrieved from the hole. The core is then cut into 1.5 -m-long sections and numbered serially from the top of the core (Fig. 4). When the core is fully recovered, the sections are numbered from 1 to 7 , with the last section shorter than $1.5 \mathrm{~m}$. The core-catcher sample is placed below the last section when the core is described, and it is labeled core catcher (CC); it is treated as a separate section.

When recovery is partial, the original stratigraphic position of the material in the cored interval is unknown. If the recovered material is contiguous we assign the top of this material to the top of the cored interval and number the sections serially from the top, beginning
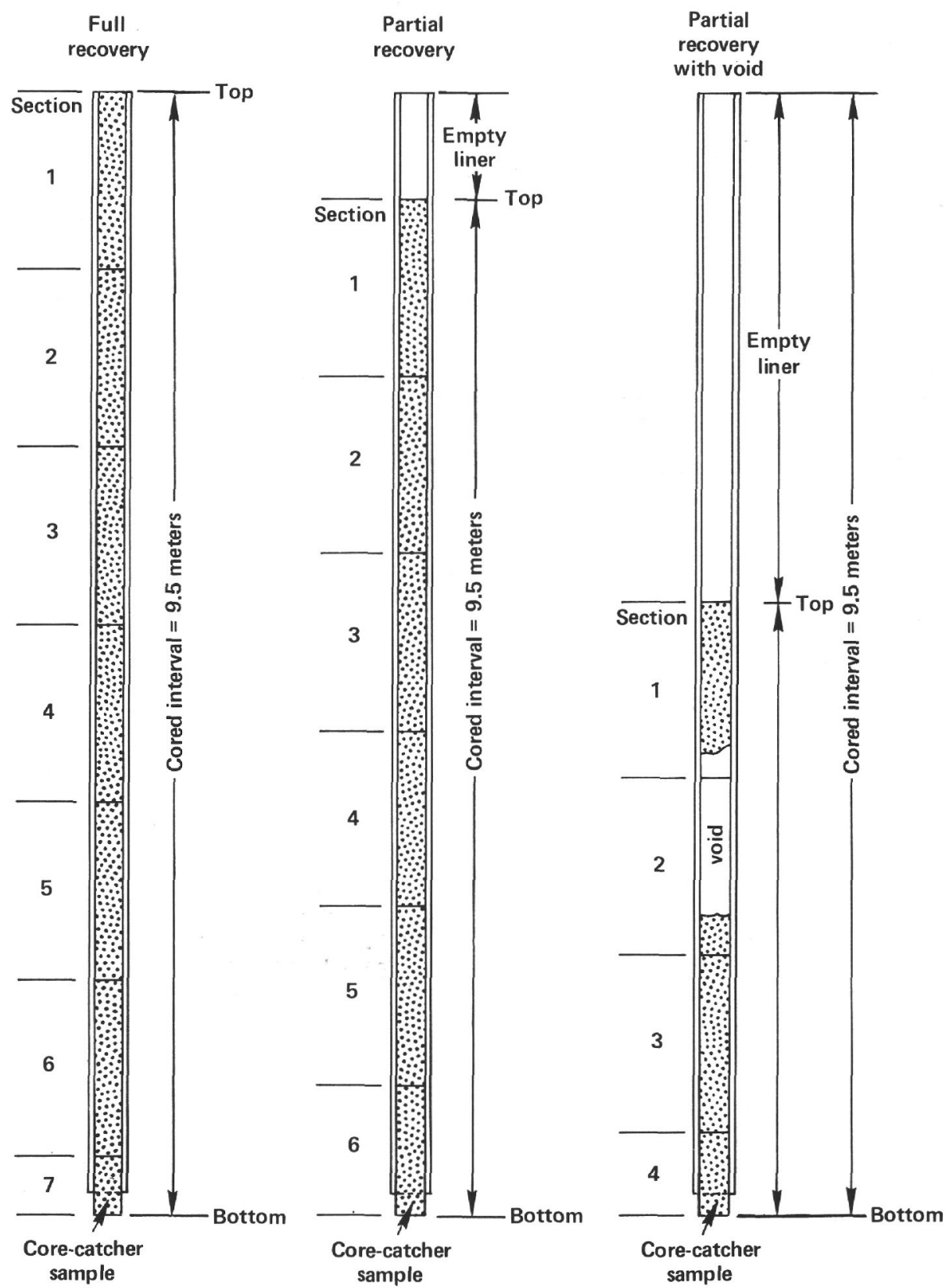

Figure 4. Diagram showing procedure in cutting and labeling of core sections. 
with Section 1 (Fig. 4). (This technique differs from the labeling system used on Legs 1 to 45 , which had a section numbered 0 but did not have a section numbered 7.) There are as many sections as needed to accommodate the length of the recovered material. For example, $4 \mathrm{~m}$ of material is divided into three sections, two upper sections each $1.5 \mathrm{~m}$ long and a final lower section only 1.0 $\mathrm{m}$ in length. If the material recovered is not contiguous, as determined by a shipboard scientist, the sections are divided and numbered serially, as with contiguous material, and gaps are labeled as voids (for sediments, as in Fig. 4) or marked by spacers (for igneous rocks; see Igneous Rocks section).

Samples are designated by the distance in centimeters from the top of each section to the top and bottom of the sample in that section. A full identification number for a sample consists of leg, site, hole, core number, and interval (in $\mathrm{cm}$ from the top of the section). For example, a sample identification number of 73-519A-4-2, 12$14 \mathrm{~cm}$ is interpreted as the sample taken from the interval 12 to $14 \mathrm{~cm}$ from the top of Section 2 of Core 4, from the second hole drilled at Site 519 during Leg 73. The depth of the sample below the seafloor is the sum of (1) the depth to the top of the cored interval (for the sample above, Core 4, the top of which is $96 \mathrm{~m}$ deep); (2) the depth to the top of the right section $(1.5 \mathrm{~m}$, to account for Section 1); (3) the depth below the top of the right section $(12 \mathrm{~cm})$. For the sample given, these variables add up to $97.62 \mathrm{~m}$. (Note, however, that sample requests should refer to the interval within a section of a core and not depth below the seafloor or sea level.) A sample from the core catcher for this core is designated 73-519A-4,CC.

\section{Handling of Cores}

A core is normally cut into $1.5-\mathrm{m}$ sections, sealed, labeled, and then brought into the core laboratory for processing. Continuous wet-bulk-density determinations using the Gamma Ray Attenuation Porosity Evaluator (GRAPE) are measured first on unsplit sections. The cores are then split longitudinally into working and archive halves. Samples are taken from the working half, including those for the determination of paleomagnetic directions and intensities, grain-size distribution, sonic velocity (by the Hamilton Frame method), wet-bulk density (by a static GRAPE technique), water content (by gravimetric analysis), carbon-carbonate content, calcium-carbonate content ("Karbonate Bomb"), geochemistry, and paleontological characteristics. Smear slides (thin sections for lithified sedimentary and igneous rocks) are prepared for each major lithology and most minor lithologies and examined microscopically. The archive half is then described and photographed. Physical disturbance by the drill bit, color, texture, structures, and the composition of the various lithologies are noted on standard core description forms.

After the cores are sampled and described, they are maintained in cold storage on board the Glomar Challenger until they can be transferred to the DSDP repository. All Leg 73 cores are presently stored at the DSDP
East Coast Repository (which is at the Lamont-Doherty Geological Observatory).

\section{Sediments and Sedimentary Rocks}

\section{Core Description Forms}

Data for each core of sediment and sedimentary rock are compiled on standard core description forms (Fig. 5). Cores acquired with the HPC are distinguished from conventional cores on these forms by the presence of the designation (HPC) after the word Core in the heading and by the expansion of the vertical scale to encompass only three sections (maximum) to allow more detailed description. For Leg 73, we added an additional column to these forms to include magnetic polarity data (Fig. 5). Magnetic polarity epochs are given in the column of this figure showing time-rock units.

The graphic lithology column of the core description form illustrates lithologic types and variations by a single symbol or combinations of two or more symbols. Each symbol corresponds to a sediment type keyed in Figure 6; the relative abundance of each component is shown by the proportion of the width of the graphic column its symbol occupies. The locations of small pebbles and patches of unique lithologies that do not extend across the entire core are indicated by solid squares and by triangular insets of the appropriate symbol, respectively (Fig. 6).

The descriptive portion of the core form includes the identification of sediment types (see following lithologic classification) and a brief description of their characteristics (i.e., color, drilling disturbance, sedimentary structures, and composition). Colors, which were determined immediately after the cores were split and still wet, follow the Geological Society of America Rock Color Chart. We recognized six categories of drilling disturbance for soft and firm sediment: (1) undisturbed-sedimentary structures are intact, with no visible deformation; (2) slightly deformed-bedding contacts are slightly bent; (3) moderately deformed-in soft sediment, bedding contacts are considerably bowed but still recognizable; firm sediment is fractured; (4) very deformedin soft sediment, bedding is completely disturbed or homogenized by drilling and sometimes shows diapirlike structures; firm sediment is broken into drilling biscuits set in a homogeneous drilling matrix; (5) soupy-intervals are water saturated, with no recognizable structures; (6) drilling breccia-indurated sediment is broken into angular fragments and mixed by the drilling process. These categories are also coded on the core forms under the column headed Drilling Disturbance (Fig. 5). The next column displays the sedimentary structures noted in the lithologic description; the key to the symbols is given in Figure 7. The compositional data come from analyses of smear slides, thin sections, and carbonate content $\left(\% \mathrm{CaCO}_{3}\right)$ done on board. The resulting data are listed in the lithologic descriptions. Individual samples are designated by two numbers separated by a hyphen (section-interval, in $\mathrm{cm}$ ), and their locations are shown by keyed symbols in the column headed Sam- 


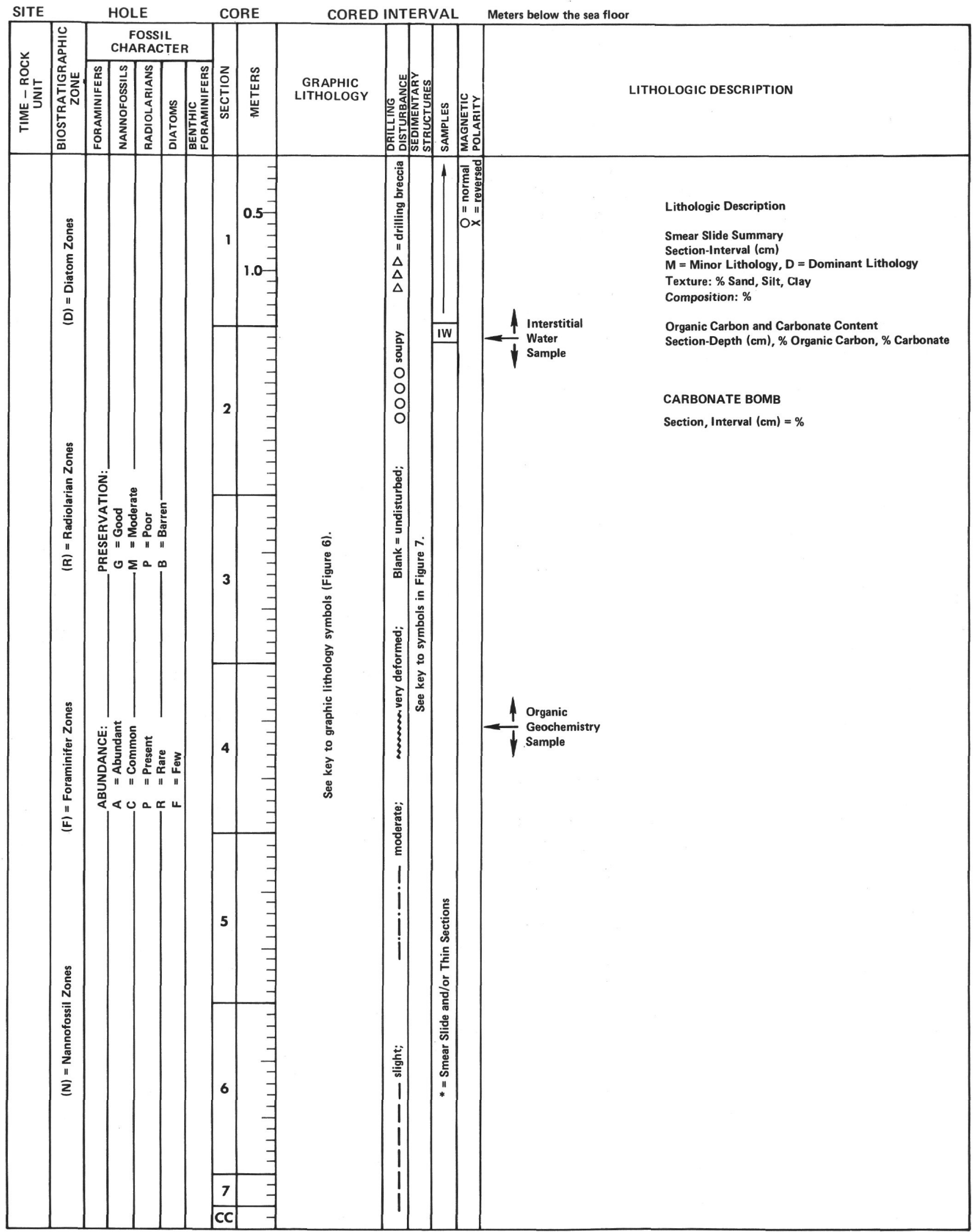

Figure 5. Sample core description form (sediment). 
Pelagic

Non-biogenic

Pelagic Clay

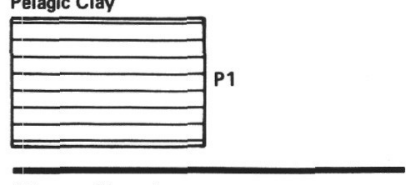

Siliceous Biogenic

Pelagic Siliceous Biogenic - Soft

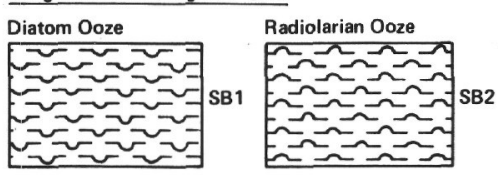

Pelagic Siliceous Biogenic - Hard

Diatomite

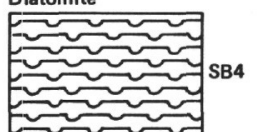

Radiolarite

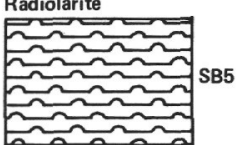

2
Vertical bar percent

\%) Designation

or Graphic Log.

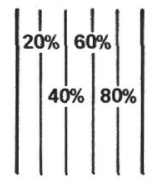

Diatom-Rad or

Siliceous Ooze

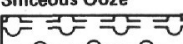

$=a=0==$

$\approx=\Omega \approx=$

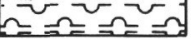

Porcellanite Chert

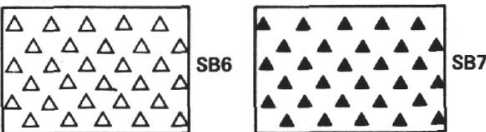

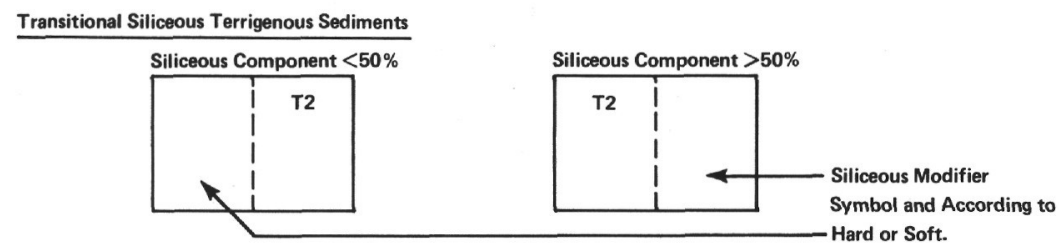

Calcareous Biogenic

Pelagic Biogenic Calcareous - Soft

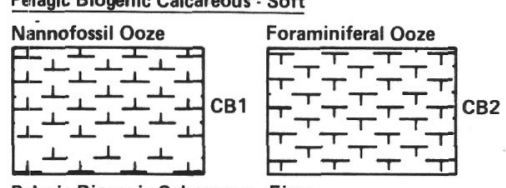

Pelagic Biogenic Calcareous - Firm

Nannofossil Chalk

Form

Pelagic Biogenic Calcareous . Hard

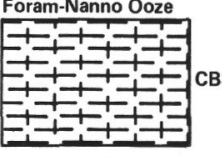

Nanno-Foram or

Foram-Nanno Chalk

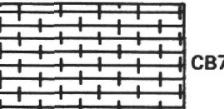

$\mathrm{CB} 7$

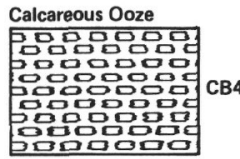

CB4

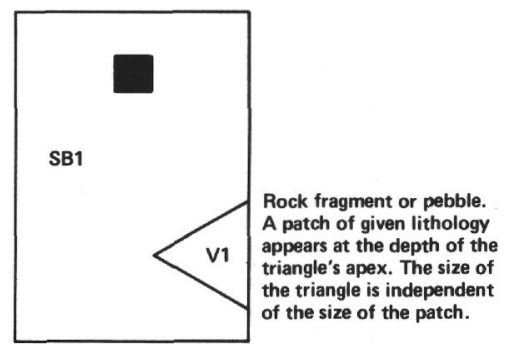

Limestone

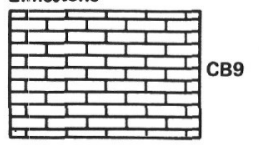

Terrigenous Sediments

Clay/Claystone

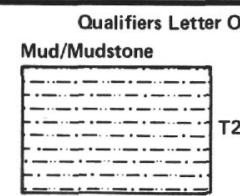

erprint (as per examples)

Zeolite A1 Glauconite A3 Siderite A4 (other may be designated)

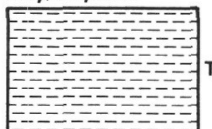

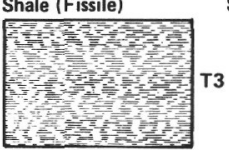

Silt/Siltstone

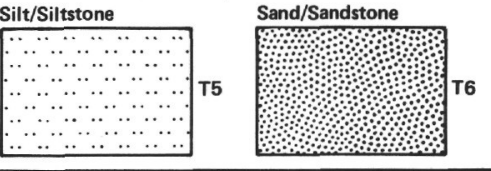

Silty Sand/

Pyroclastic
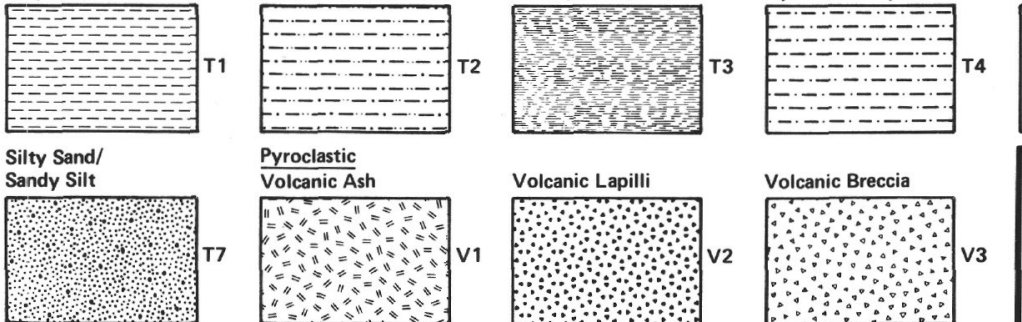

Volcanic Breccia
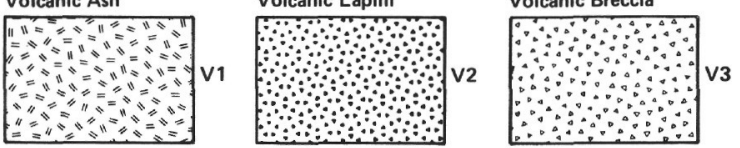

Basalt pebble

(B)

Special Rock Types

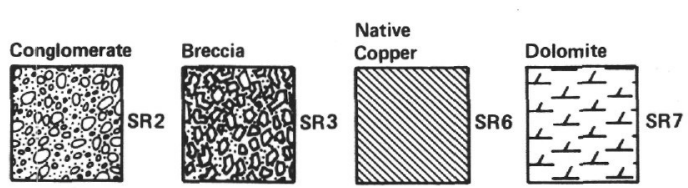

Concretions

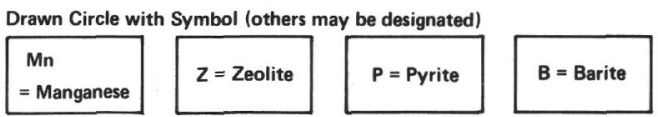

For special rock types not shown check with DSDP Staff Scientist for symbol and number.

Figure 6. Symbols used in graphic lithology column of core description form (sediment). 


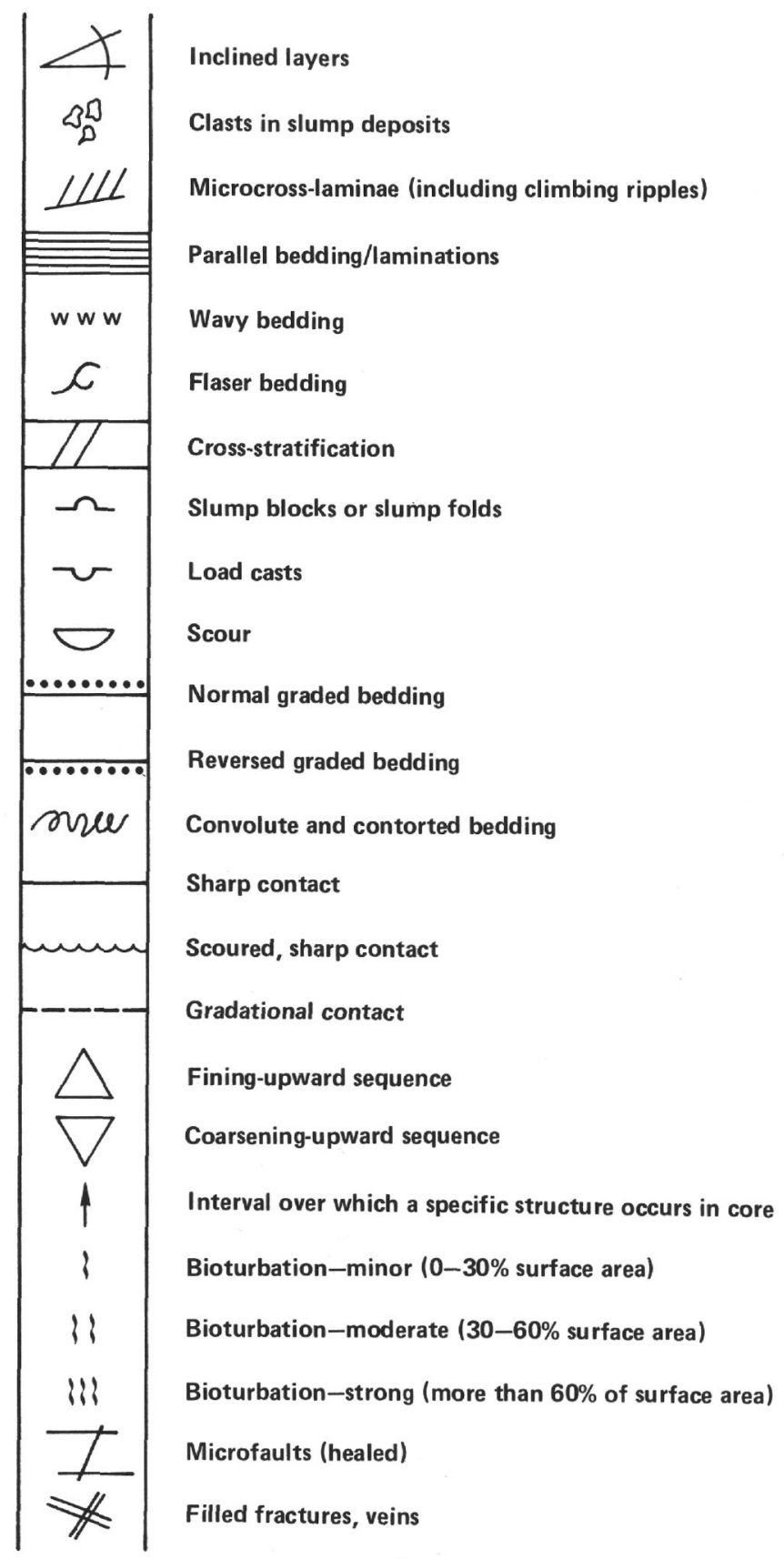

Figure 7. Symbols for sedimentary structures used on sediment core description forms.

ples (Fig. 5). Locations and intervals of interstitial water samples (IW) are also shown in this column. Biostratigraphic zones and age assignments appear in the columns at the left of the core description form.

\section{Lithologic Classification of Sediments}

We used a modified version of the lithologic classification of sediments devised by the JOIDES Panel on Sedimentary Petrology and Physical Properties and adopted by the JOIDES Planning Committee in March 1974. (For the original JOIDES classification see Ross et al., 1978, pp. 14-15.) These modifications, which primarily represent changes in the compositional class boundaries of calcareous and siliceous sediments, are explained below. This classification is descriptive rather than genetic, and divisions between different types of sediment are somewhat arbitrary. We treat lithologic types not covered in this classification as a separate category termed Special Rock Types. A brief outline of the conventions and descriptive data used to construct this classification follows.

\section{Conventions and Descriptive Data}

\section{Composition and Texture}

In this classification the only criteria used to classify sediment or sedimentary rock are composition and texture. Composition is most important for describing sediments deposited in the open ocean; texture becomes significant for hemipelagic and nearshore sediments. Both types of information come principally from the visual examination of smear slides under a petrographic microscope. Estimates are made of the areal abundance and size of the components on the slide, and they may differ somewhat from the more accurate results of volumetric analyses of grain size, carbonate content, and mineralogy (see Special Studies section). Quantitative estimates of distinctive minor components can be expected on the basis of past experience to be accurate within 1 or $2 \%$; accuracy is worse for the major constituents $( \pm 10 \%)$. All smear slide estimates were made on board. Carbonate content is difficult to estimate from smear slides. Therefore, for many cores we determined the percentage of carbonate by using the "Karbonate Bomb" technique of Müller and Gastner (1971). This method involves treating a powdered sample with $\mathrm{HCl}$ in a closed cylinder. The resulting pressure of $\mathrm{CO}_{2}$ is proportional to the carbonate content $\left(\mathrm{CaCO}_{3}\right)$ of the sample, and this value is converted to percent $\mathrm{CaCO}_{3}$ by using the calibration factor of the manometer. The accuracy of this method is $\pm 5 \%$. The carbonate content determined in this manner is listed on the core description forms below the lithologic description.

Textures of sediments estimated from smear slides and listed as percent sand-silt-clay in the smear slide summary on the core description forms include all constituents. Thus, a foraminiferal ooze will have a greater percentage of sand-sized particles than a nannofossil ooze because of the different sizes of the tests of the two fossil groups. This convention causes some confusion when terrigenous sediments that contain a significant number of microfossils are named. For example, a diatomaceous mud may have fewer silt-sized terrigenous particles (e.g., quartz and feldspar) than a nannofossil mud simply because many diatoms are silt sized and are included as such in the textural estimate. However, we have chosen fairly broad compositional class boundaries (see below) for mixed terrigenous and biogenic sediments in order to minimize this effect.

When it was appropriate we used one or more modifiers in naming the type of sediment encountered. In all cases the dominant component appears last in the name; minor components precede, with the least common constituent listed first. If minor constituents occur in 
amounts less than $10 \%$ they are not included in the name. This convention also holds for zeolites, $\mathrm{Fe}$ - and Mn-micronodules, and other indicators of very slow rates of sedimentation or nondeposition. Often these minerals are conspicuous even though greatly diluted, and they are sometimes included in the name of the sediment or mentioned in the lithologic description.

\section{Induration of Sediments}

We recognize three classes of induration or lithification for calcareous sediments and sedimentary rocks in which the carbonate content is greater than $50 \%$ and only two classes for all other lithologic types.

1. Calcareous sediments and sedimentary rocks in which carbonate content is $>50 \%$ (categories after Gealy et al., 1971).

a. Soft $=$ ooze; has little strength and readily deforms under pressure of finger or broad blade of spatula.

b. Firm = chalk and marl; partially lithified and readily scratched with fingernail or edge of spatula.

c. Hard = limestone; well lithified and cemented; resistant or impossible to scratch with fingernail or edge of spatula.

2. Siliceous sediments in which silica content is $>50 \%$. a. Soft $=$ ooze; readily deformed by finger or broad blade of spatula.

b. Hard = diatomite, chert, or porcellanite; core must be cut with band saw or diamond saw.

3. Terrigenous sediments in which terrigenous components are $>50 \%$.

a. Soft = sand, silt; clay, mud (or combinations of these); readily deformed by finger or broad blade of spatula.

b. Hard = sandstone, siltstone, claystone, etc. (i.e., suffix "stone" added); core must be cut with band saw or diamond saw.

\section{Types of Sediments and Compositional Class Boundaries}

We distinguish four types of sediment: (1) siliceous biogenic sediments, (2) calcareous biogenic sediments, (3) terrigenous sediments, and (4) volcanogenic sediments and pyroclastic rocks. Figure 8 summarizes this classification, except for the volcanogenic sediments. Each type of sediment is discussed briefly below. An additional category, Special Rock Types, is also included.

\section{Siliceous Biogenic Sediments}

These are sediments in which biogenic silica or authigenic silica (opal-CT and/or quartz) makes up at least $50 \%$ of the sediment. If the siliceous component is be-

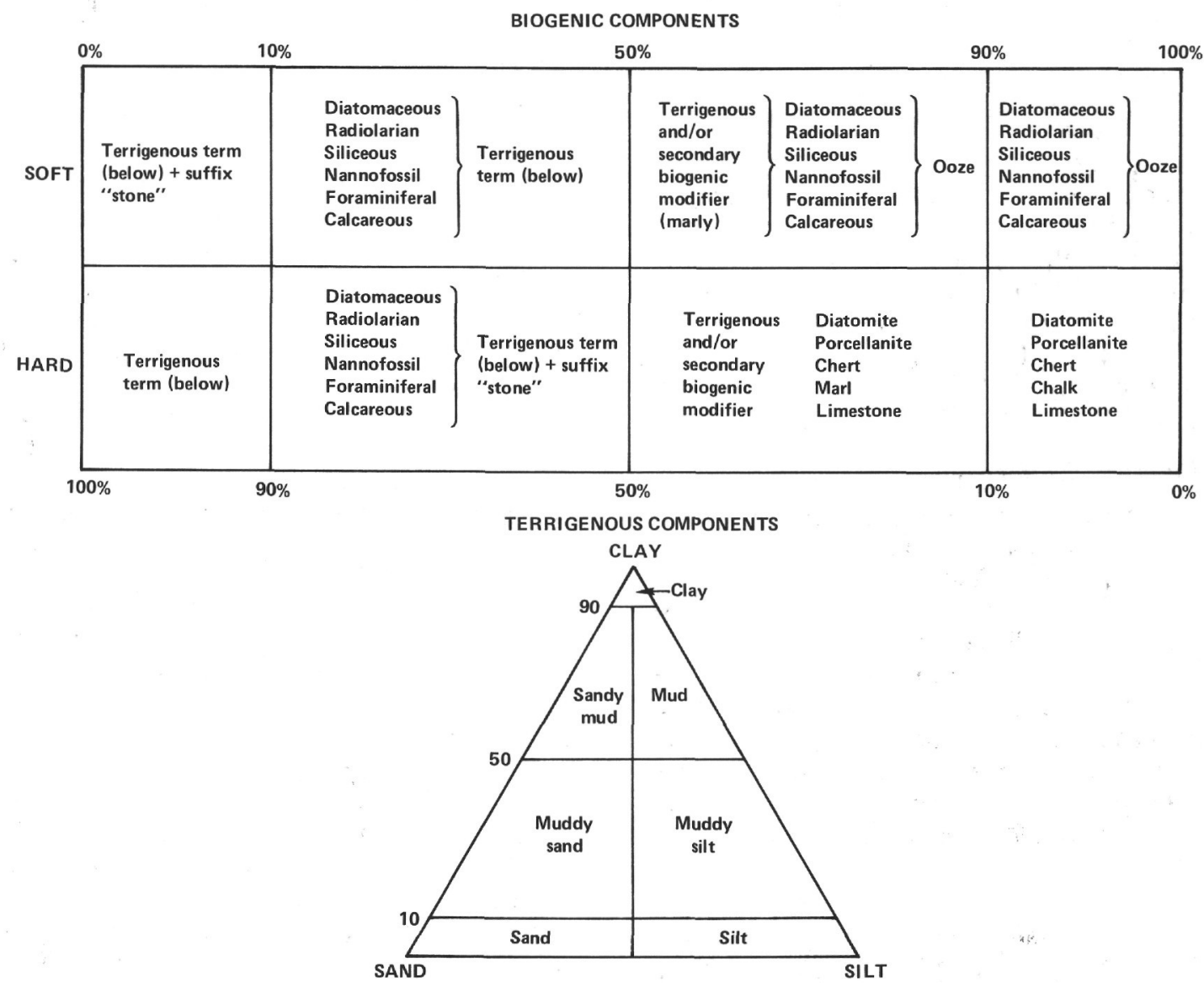

Figure 8. Lithologic classification of sediments and sedimentary rocks used on Leg 73. 
tween 50 and $90 \%$, the terrigenous (most abundant textural class, i.e., sand, silt, or clay), calcareous biogenic, or volcanogenic modifier is retained. For example, clayey diatomaceous ooze describes a soft sediment with at least $10 \%$ clay and between 50 and $90 \%$ diatoms. If the siliceous component exceeds $90 \%$, modifiers are dropped. A radiolarian ooze would have $<10 \%$ clay or carbonate and $>90 \%$ radiolarians. If the siliceous biogenic component is between 10 and $50 \%$, the names for terrigenous or calcareous biogenic sediments or pyroclastic rocks apply, with the dominant siliceous constituent as a qualifier. Silica in amounts $<10 \%$ is not acknowledged in the name. These terms apply to soft sediments (Fig. 8).

For hard siliceous rocks, siliceous microfossils are often absent. If they have been dissolved and replaced by opal-CT and/or quartz and these minerals make up $>50 \%$ of the rock, the terms porcellanite and chert apply. We follow the definitions of Taliaferro (1934), Bramlette (1946, p. 57), and Keene (1975) for these two rocks: chert is a hard, conchoidally fracturing varicolored sedimentary rock with semivitreous, vitreous, or waxy luster and consisting dominantly of silica; and porcellanite ${ }^{2}$ is a siliceous sedimentary rock with a dull or matte luster resembling that of unglazed porcelain. It is hard, dense, more vitreous than chert, and commonly has a lower silica content. These definitions differ from previous DSDP usage in that chert and porcellanite are textural terms independent of the silica polymorph present. Previous DSDP usage equated cherts with quartzose rocks and porcellanite with rocks in which opal-CT (cristobalite) is the dominant silica mineral. Recent studies, especially of Neogene siliceous rocks, have shown that rocks that qualify as chert and porcellanite in the textural sense noted above may contain opal-CT and/or quartz and chalcedony. Thus, the usage of these terms should not be based on the nature of the silica phase. When used in a textural sense, these terms are useful field designations. Qualifiers such as "opal-CT" and "quartzose" may be added when the dominant silica phases are determined by X-ray diffraction or petrographic work.

\section{Calcareous Biogenic Sediments}

These are sediments in which biogenic carbonate or carbonate of indeterminate origin (cement or recrystallized carbonate) comprise at least $50 \%$ of the sediment. If the carbonate component is between 50 and $90 \%$, the terrigenous (or marly), siliceous biogenic, or volcanogenic modifiers are retained. For example, clayey or marly nannofossil ooze describes a soft sediment with at least $10 \%$ clay and between 50 and $90 \%$ calcareous nannofossils. If the calcareous component exceeds $90 \%$, the modifiers are dropped. A nannofossil ooze would have $<10 \%$ clay or silica and $90 \%$ calcareous nannofossils.

\footnotetext{
2 The spelling of porcellanite has been somewhat controversial. Taliaferro (1934) originally proposed the term as porcelanite. Durham $(1974$, p. 111) indicates that the term is derived from the Italian porcellana rather than the English porcelain. For the sake of continuity we retain the DSDP spelling of porcellanite.
}

If the calcareous biogenic component is between 10 and $50 \%$, the names for terrigenous or siliceous biogenic sediments or pyroclastic rocks apply, with the dominant calcareous constituent as a qualifier. Carbonate less than $10 \%$ is not acknowledged in the name. These terms apply to soft sediments (Fig. 8).

For firm and hard calcareous rocks with carbonate contents $>50 \%$ the terms marl, chalk, and limestone apply. If the carbonate content is between 50 and $90 \%$ the term marl is used and the terrigenous modifier is retained. For example, a clayey limestone has at least $10 \%$ clay and 50 to $90 \%$ carbonate. The modifiers are dropped when the carbonate content exceeds $90 \%$. If the carbonate content is less than $50 \%$, the terrigenous, siliceous biogenic, or volcanogenic names apply, with the dominant carbonate type retained as a qualifier. Carbonate is not acknowledged in the name if it is present in amounts $<10 \%$. Note that we use the qualifier "calcareous" to designate carbonate of indeterminate origin.

\section{Terrigenous Sediments}

The textural classification of terrigenous sediments follows that shown in Figure 8, with grain-size limits as defined by Wentworth (1922). Sediments and sedimentary rocks are assigned terrigenous names according to their textural classification when these components exceed $50 \%$. If the terrigenous component is between 50 and $90 \%$ the biogenic or volcanogenic modifier is retained. For example, a nannofossil mud contains $>10 \%$ calcareous nannofossils and 50 to $90 \%$ mud. The biogenic or volcanogenic modifier is dropped when that component is less than $10 \%$. For hard terrigenous sediments the suffix "stone" is added.

\section{Volcanogenic Sediments and Pyroclastic Rocks}

We arbitrarily distinguish pyroclastic rocks from volcanogenic sediments by using $50 \%$ as the pivotal percentage, pyroclastic rocks having $>50 \%$ volcanic components, volcanogenic sediments $<50 \%$. Wentworth and Williams' (1932) textural and compositional classification applies for the pyroclastic rocks. The textural groups are as follows: $>32 \mathrm{~mm}-$ volcanic breccia; 4-32 $\mathrm{mm}$-volcanic lapilli (lapilli tuff when indurated); and $<4 \mathrm{~mm}$-volcanic ash (tuff when indurated). The compositional breakdown is vitric (glass), crystalline, or lithic, according to the most common constituent. Qualifiers are used when the volcanic components are between 50 and $90 \%$. For example, a muddy vitric ash contains $>10 \%$ clay and 50 to $90 \%$ ash composed mainly of glass shards. Terrigenous and biogenic modifiers are dropped if $<10 \%$.

When the volcanic component is $<50 \%$, the terminology and class boundaries for terrigenous (and, less often, biogenic) sediments applies. The modifier "tuffaceous" encompasses both ash and lapilli when either or both of these components occur in amounts between 10 and $50 \%$. Thus, a tuffaceous muddy sand (stone) contains 10 to $50 \%$ ash and/or lapilli and 50 to $90 \%$ muddy sand. 


\section{Special Rock Types}

Special rock categories used on Leg 73 include (1) pebbly marl, which is analogous to pebbly mudstone but composed mostly of carbonate material, and (2) basalt, which occurs as fragments in sediment at Site 519 .

\section{Special Studies of Sediments}

\section{Organic Carbon and Carbonate Content}

Carbonate content was determined on board by using the "Karbonate Bomb" method already described. The data appear in the core description forms as $\% \mathrm{CaCO}_{3}$. Additional measurements of carbonate content and organic carbon content done at the DSDP sediment laboratory are given in Appendix I (to this vol.).

\section{Grain-Size Analysis}

We selected samples to be analyzed by standard sieve and pipette methods at the DSDP sediment laboratory. These data are listed in Appendix I.

\section{Biostratigraphy}

One of the more significant achievements of Leg 73 was the correlation of the geomagnetic field history and the biostratigraphic zonations (Tauxe et al.; Poore et al.; Hsü et al. [all this vol.]). Some radiometric ages were obtained from the basement and sills at the Leg 73 sites (Dietrich et al., this vol.), and these dates should be added to the growing body of radiometric data.

Two primary approaches are used to develop time scales for the Cenozoic and Mesozoic. One is based on the assumption of constant seafloor spreading rates (Heirtzler et al., 1968); the other is based on radiometric dates obtained from separate stratigraphic horizons (Lowrie and Alvarez, 1981). The use of either system involves a good deal of subjectivity, and there is no consensus as to which approach or which set of dates is correct (LaBrecque et al., in press). The authors in this volume have used different approaches, according to their preferences. In most cases the variation between the time scales is less than $10 \%$, and reference is made to the appropriate time scale. One proposed time scale is that of Hsü et al. (this vol.), which is shown in Figure 9 and incorporates the magneto-biostratigraphic correlations of Tauxe et al. and Poore et al. (this vol.). The proposed numerical ages are discussed in detail in Hsü, Percival, et al. (this vol.).

For each of the sequences that passed a good carbonate ooze section and good biostratigraphic and/or magnetostratigraphic control (i.e., Holes 519, 521, 522, and 523), the foraminiferal preservation traits were examined in detail to provide a measure of dissolution. Two parameters were measured: (1) the proportional contribution of benthic foraminiferal tests to the total foraminiferal assemblage, and (2) the degree of fragmentation of the planktonic foraminiferal tests. Both parameters were measured on the size fraction greater than $125 \mu \mathrm{m}$. Any grain recognizable as a planktonic foraminifer that constituted less than $95 \%$ of a whole test was counted and compared to the number of whole tests. The proportion of benthic tests was calculated by comparing the number of grains that constituted more than half of benthic test to the number of grains that constituted more than half of a planktonic test.

\section{Paleomagnetics}

Onboard equipment used in the paleomagnetic study of recovered sediments, sedimentary rocks, and igneous rocks included a Digico spinner magnetometer with its associated Digico M16V computer and a Schonstedt Geophysical Specimen Demagnetizer (Model GSD-1). A portable magnetic susceptibility bridge Bison Instruments Magnetic Susceptibility system (Model 3101) was used to measure the susceptibility.

\section{Igneous Rocks}

\section{Visual Core Description Forms}

All igneous rocks were split by using a rock saw into working and archive halves and were described and sampled on board. Figure 10 shows a composite of the visual core description form used to describe the igneous rocks recovered on Leg 73 . On this form, each section of core is described under five column headings: (1) piece number, (2) graphic representation, (3) orientation, (4) shipboard studies, and (5) alteration.

In the graphic representation column each piece is accurately drawn. Such features as texture, glassy margins, and vesicles are coded according to the symbols given in Figure 11. Two closely spaced horizontal lines in this column indicate the location of styrofoam spacers taped between pieces inside the liner. Each piece is numbered sequentially from the top of the section, beginning with number 1; these numbers are entered in the Piece Number column. Pieces are labeled on the rounded surface rather than the flat slabbed face. Pieces that fit together before the cores were split are given the same number but are lettered consecutively (1A, 1B, 1C, etc). Spacers are placed only between pieces that did not fit together; those pieces are given different numbers. Spacers may or may not indicate that material between pieces is missing (i.e., not recovered). Cylindrical pieces longer than the diameter of the liner have arrows in the Orientation column indicating that top and bottom have not been reversed as a result of drilling and recovery. Arrows also appear on the labels of these pieces on both archive and working halves.

The column marked Shipboard Studies designates the location and the type of onboard measurements made on a sample. Entries in the column headed Alteration use the code given in Figure 11 to indicate the degree of alteration.

Figure 10 gives an outline of the core descriptions that appear in the right-hand margin of the visual core description form for igneous rocks. If more than one core appears on the core form, these data are listed below the description of the first core. As many cores as space allows are included on one visual core description form. When space for descriptions is inadequate on this form, 


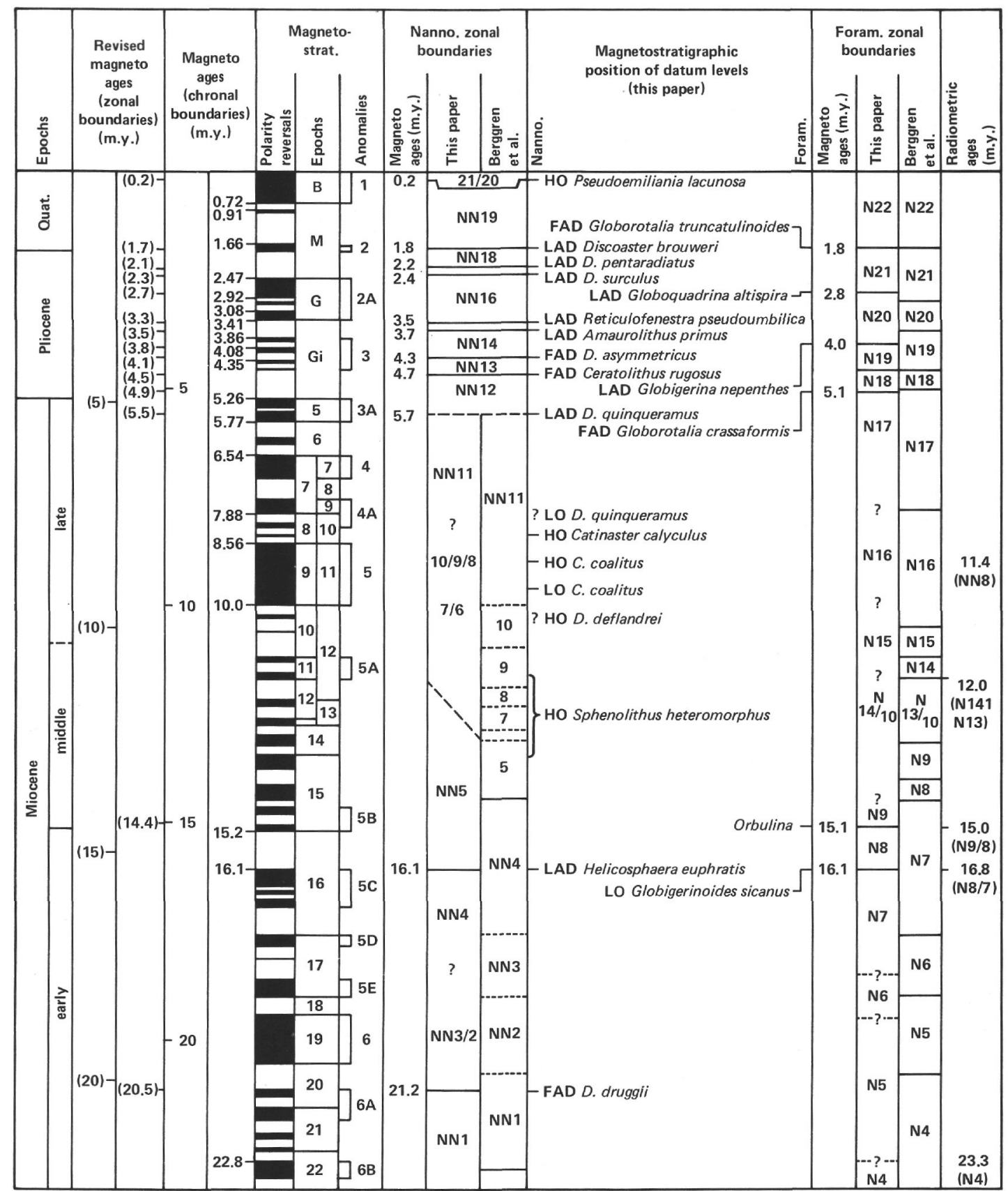

Figure 9. Biostratigraphic-magnetostratigraphic time scale. For a fuller explanation see Hsü, Percival, et al. (this vol.).

these data appear on following or facing pages. However, in no case does information from one core appear on successive core forms.

For each core, the core number, sections, and depth interval recovered are listed, followed by the major and minor rock types and a short description. This section data are tallied below this, then shipboard data.

\section{Classification of Igneous Rocks}

We informally classified the igneous rocks recovered on Leg 73 according to mineralogy and texture as determined from the visual inspection of hand specimens and thin sections. Terms such as tholeiite and alkali basalt depend upon a combination of mineralogical and chem- ical data. Textural terms follow Williams et al. (1954, p. 406), with the following modifications.

First, a "very fine-grained" term is added to the scale used for Leg 52. Thus, the scale used is as follows: very coarse-grained->0.5 mm; coarse-grained-1.1-0.05 $\mathrm{mm}$; medium-grained-0.05-0.1 $\mathrm{mm}$; fine-grained$0.01-0.05 \mathrm{~mm}$; and very fine-grained $-0.01 \mathrm{~mm}$.

Second, the textural term spherule (or spherulite) is defined in more detail than in previous reports. The characteristics of this feature, which are based on petrographic observations made for Hole 579A, are as follows: they are in and on the border of glassy margins; they represent an aggregate of radiating fibers too fine to resolve optically with a $63 \times$ objective lens; they are 


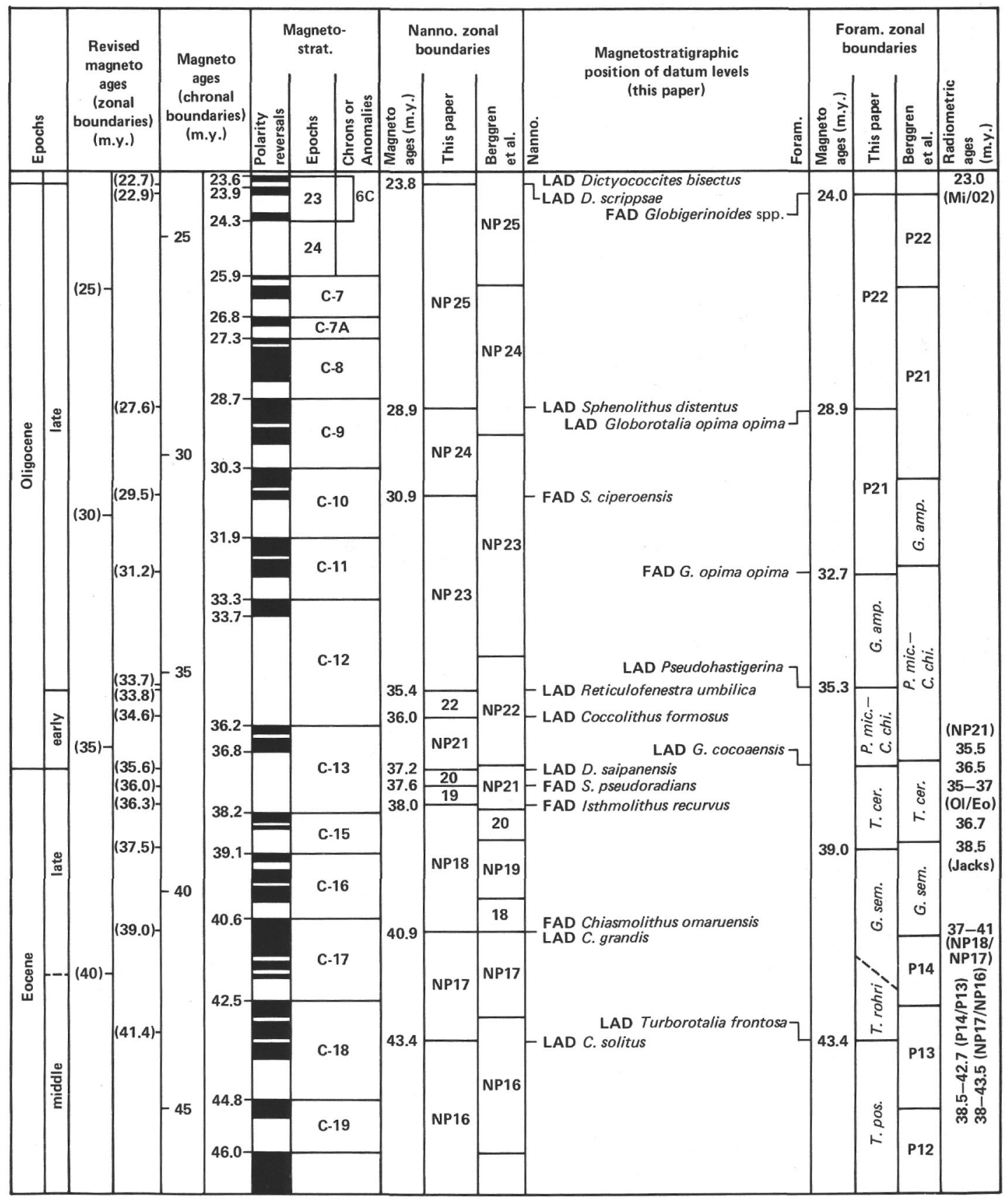

Figure 9. (Continued).

rounded to elliptical in shape, in sheaves of bow-tie and fan shapes; they range in size from 0.05 to $0.7 \mathrm{~mm}$; the fibers are mostly length-slow; and the core mineral is equant or elongated olivine, plagioclase microlite, or not apparent.

No chemical analyses were done on board. The chemical data discussed in the site chapters come from the results presented by Dietrich et al. (this vol.).

\section{Physical Properties}

Boyce (1976) describes in considerable detail the equipment, methods, and corrections routinely used by shipboard scientists to measure the physical properties of sediments and rocks recovered at the deep sea drilling sites. On Leg 73 we determined saturated bulk density by using the GRAPE and the gravimetric technique. Porosity was calculated from GRAPE and gravimetric measurements, water content from gravimetric measurements, and sonic velocity by using the Hamilton Frame velocity meter. Shear strength was measured on undisturbed sediments (see Boyce, 1977). For density and porosity calculations we assume grain densities of $2.60 \mathrm{~g} /$ cc for chert, $2.70 \mathrm{~g} / \mathrm{cc}$ for sediments and limestone, and $2.90 \mathrm{~g} / \mathrm{cc}$ for igneous rocks. Assumed pore fluid densities were $1.025 \mathrm{~g} / \mathrm{cc}$ (true) and $1.128 \mathrm{~g} / \mathrm{cc}$ (corrected). In addition, we determined thermal conductivities of sediments and rocks by using the needle probe method. All 


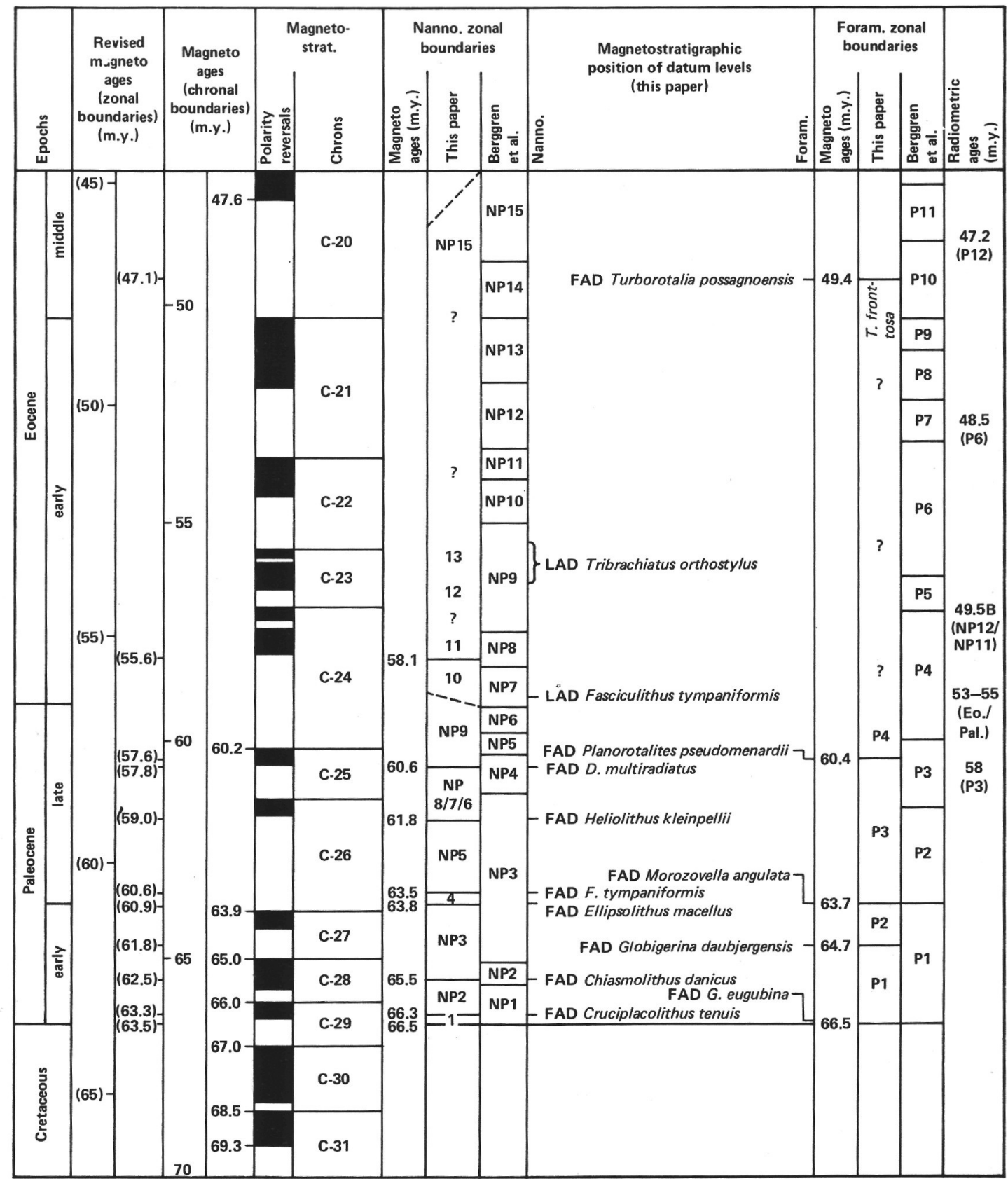

Figure 9. (Continued).

samples were allowed to equilibrate to room temperature ( $4 \mathrm{hr}$. minimum) before each conductivity measurement. Listings of these data are available on request from the Deep Sea Drilling Project.

\section{Geochemical Measurements}

Interstitial water extracted from selected sediment samples was analyzed on board the Glomar Challenger for salinity, titration alkalinity, dissolved calcium, magnesium, and chloride by using the techniques described by Gieskes (1974).

\section{Photography}

Color and black and white negatives of whole cores are available for consultation. In addition, black and white negatives are archived at DSDP for the closeup documentation of special structures. Table 2 lists those from Leg 73 . The photographs are available on a charge and time available basis.

\section{REFERENCES}

Boyce, R. E., 1976. Definitions and laboratory techniques of compressional sound velocity parameters and wet-water content, wet-bulk density, and porosity parameters by gravimetric and gamma ray attenuation techniques. In Schlanger, S. O., Jackson, E. D., et al., Init. Repts. DSDP, 33: Washington (U.S. Govt. Printing Office), 931-958

1977. Deep Sea Drilling Project procedures for shear strength measurement of clayey sediment using modified Wykeham Farrance laboratory vane apparatus. In Barker, P. F., Dalziel, I. W. D., et al., Init. Repts. DSDP, 36: Washington (U.S. Govt. Printing Office), 1059-1068. 
Bramlette, M. N., 1946. The Monterey Formation of California and the origin of its siliceous rocks. Geol. Surv. Prof. Pap. (U.S.) No. 212.

Cande, S. C., Larson, R. L., and LaBrecque, J. L., 1978. Magnetic lineations in the Jurassic Quiet Zone. Earth Planet. Sci. Lett., 42: 153-166.

Durham, D. L., 1974. Geology of the southern Salinas Valley. U.S. Geol. Surv. Prof. Pap. (U.S.) No. 819.

Gealy, E. L., Winterer, E. L., and Moberly, R. M., Jr., 1971. Methods, conventions, and general observations. In Winterer, E. L., Riedel, W. R., et al., Init. Repts. DSDP, 7, Pt. 1: Washington (U.S. Govt. Printing Office), 9-26.

Gieskes, J. M., 1974. Interstitial water studies, Leg 25. In Simpson, E. S. W., Schlich, R., et al., Init. Repts. DSDP, 25: Washington (U.S. Govt. Printing Office), 361-394.

Heirtzler, J. R., Dickson, G. O., Herron, E. M., Pittman, W. C., III, and LePichon, X., 1968. Marine magnetic anomalies, geomagnetic field reversals and motions of the ocean floor and continents. $J$. Geophys. Res., 73:2119-2136.

Keene, J. B., 1975. Cherts and porcellanites from the North Pacific, DSDP, Leg 32. In Larson, R. L., Moberly, R., et al., Init. Repts. $D S D P$, 32: Washington (U.S. Govt. Printing Office), 429-507.

LaBrecque, J. L., Hsü, K. J., Carman, M. F., Karpoff, A. M., McKenzie, J. A., Percival, S. F., Petersen, N. P., Pisciotto, K. A., Schreiber, E., Tauxe, L., Tucker, P., Weissert, H. J., and Wright, R., in press. DSDP Leg 73: contributions to Paleogene stratigraphy in nomenclature, chronology, and sedimentation rates. Paleogeogr. Paleoclimatol. Paleoecol.

LaBrecque, J. L., Kent, D. V., and Cande, S. C., 1977. Revised magnetic polarity time scale for Late Cretaceous and Cenozoic time. Geology, 5:330-335.

Larson, R. L., and Hilde, T. W. C., 1975. A revised time scale of magnetic reversals for the Early Cretaceous, Late Jurassic. J. Geophys. Res., 80:2586-2594.
Lowrie, W., and Alvarez, W., 1981. One hundred million years of geomagnetic polarity history. Geology, 9:392-397.

Mathews, T., 1939. Tables of the Velocity of Sound in Pure Water and Sea Water for Use in Echo Sounding and Sound-Ranging: London (Admiralty Hydrogr. Dept.).

Müller, G., and Gastner, M., 1971. The "Karbonate-Bomb," a simple device for the determination of the carbonate content in sediments, soils and other materials. Neues Jahr. Mineral. Monatsh., $10: 466-469$.

Opdyke, N. D., Burckle, L. H., and Todd, A., 1974. The extension of the magnetic time scale in sediments of the Central Pacific Ocean. Earth Planet. Sci. Lett., 22:300-306.

Ross, D. A., Neprochnov, Y. P., and Supko, P. R., 1978. Introduction and explanatory notes, Leg 42B, Deep Sea Drilling Project. In Ross, D. A., Neprochnov, Y. P., et al., Init. Repts. DSDP, 42, Pt. 2: Washington (U.S. Govt. Printing Office), 3-15.

Taliaferro, N. L., 1934. Contraction phenomena in cherts. Geol. Soc. Am. Bull., 45:189-232.

Theyer, F., and Hammond, S. R., 1974. Paleomagnetic polarity sequence and radiolarian zones, Brunhes to Polarity Epoch 20. Earth Planet. Sci. Lett., 22:307.

Wentworth, C. K., 1922. A scale of grade and class terms of clastic sediments. J. Geol., 30:377-390.

Wentworth, C. K., and Williams, H., 1932. The classification and terminology of the pyroclastic rocks. Bull. Nat. Res. Counc., 80: 10-53.

Williams, H., Turner, F. J., and Gilbert, C. M., 1954. Petrography: An Introduction to the Study of Rocks in Thin Section: San Francisco (W. H. Freeman and Co.).

Date of Initial Receipt: July 6, 1982 


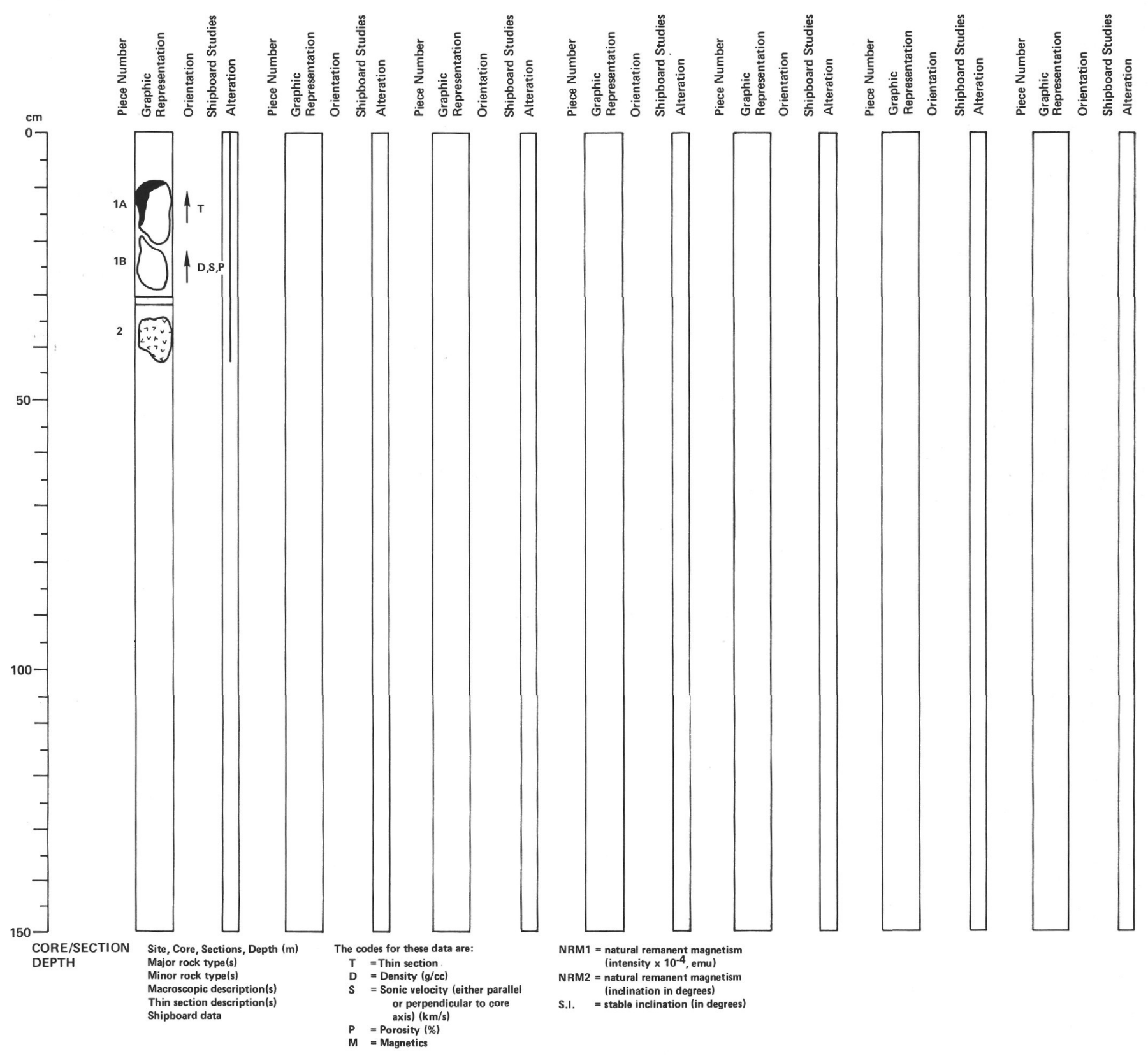

Figure 10. Visual core description form (igneous rocks). 
TEXTURE:

Used in graphic representation column

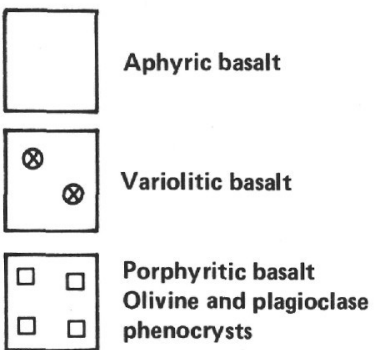

\begin{tabular}{|lll}
\hline$\square$ & $\mathrm{X}$ & $\begin{array}{l}\text { Olivine plagioclase } \\
\text { and clinopyroxene } \\
\text { phenocrysts }\end{array}$ \\
\hline & $\mathrm{X}$ & phenoch
\end{tabular}

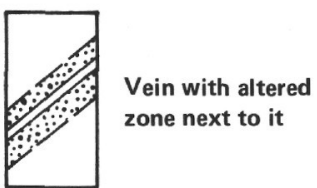

$\begin{array}{lll}x & x \\ x & x \\ x & x \\ x & x\end{array}$ Gabbro

\begin{tabular}{|l|l}
$v$ & $v$ \\
$v$ & $v$ \\
$v$ & $v$
\end{tabular} \mid $\begin{aligned} & \text { Diabase and } \\
& v \text { Metabasalt }\end{aligned}$

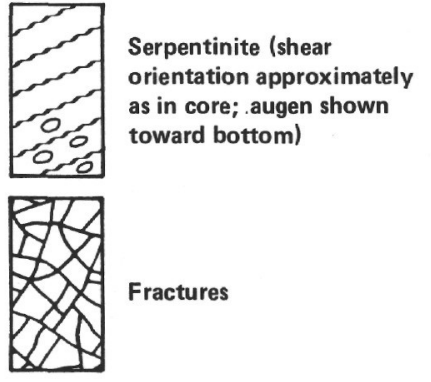

WEATHERING ALTERATION

Used in alteration column

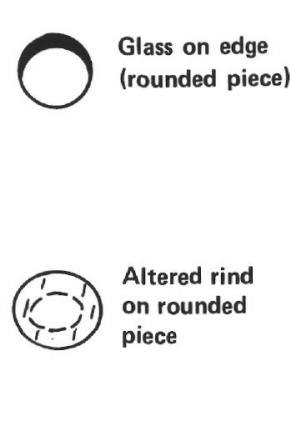

$\square$

Very fresh

(no discoloration)
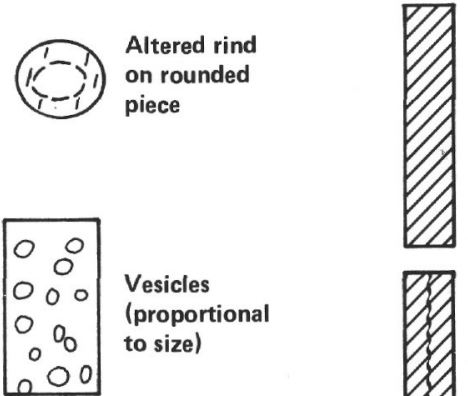

Slightly

altered

(slight discoloration,

with fresh patches)

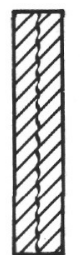

Moderately

altered

(complete discoloration,

major minerals

still fresh)

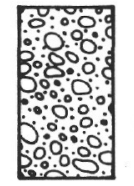

Breccia

(as graphic

as possible)

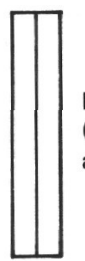

Badly altered

(discolored, most minerals

altered or stained)

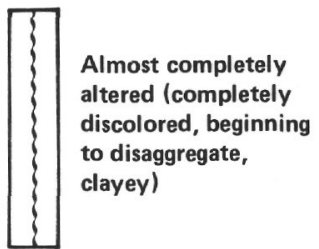

Figure 11. List of texture and alteration symbols used for igneous rocks. 


\section{K. J. HSÜ, J. LABRECQUE, K. A. PISCIOTTO}

Table 2. Index of detailed photographs of Leg 73 cores (photographs are black and white).

\begin{tabular}{|c|c|c|c|c|c|}
\hline Negative & $\begin{array}{l}\text { Sample } \\
\text { (interval in } \mathrm{cm} \\
\text { or piece) }\end{array}$ & Negative & $\begin{array}{l}\text { Sample } \\
\text { (interval in } \mathrm{cm} \\
\text { or piece) }\end{array}$ & Negative & $\begin{array}{l}\text { Sample } \\
\text { (interval in } \mathrm{cm} \\
\text { or piece) }\end{array}$ \\
\hline 1 & $519-4-3,35-55$ & 46 & $520-29-2,30-60$ & 88 & $524-9-6,0-10$ \\
\hline 2 & $519-4-3,55-75$ & 47 & $520-29-2,60-90$ & 89 & $524-10-2,80-95$ \\
\hline 3 & $519-5-2,40-70$ & 48 & $520-29-2,90-120$ & 90 & $524-10-3,45-65$ \\
\hline 4 & $519-5-2,40-75$ & 49 & $521-7-1,110-140$ & 91 & $524-10-5,50-70$ \\
\hline 5 & $519-5-2,75-110$ & 50 & $521-7-2,0-30$ & 92 & $524-10-5,80-100$ \\
\hline 6 & $519-8-2,50-80$ & 51 & $521-11-1,70-95$ & 93 & $524-11-3,60-85$ \\
\hline 7 & $519-8-2,80-110$ & 52 & $521-11-1,95-120$ & 94 & $524-12-2,5-25$ \\
\hline 8 & $519-16-1,20-50$ & 53 & $522-4-2,20-50$ & 95 & $524-12-3,75-110$ \\
\hline 9 & $519-16-1,50-80$ & $53 \mathrm{~A}$ & $522-4-3,25-45$ & 96 & $524-12-4,0-35$ \\
\hline 10 & $519-16-1,80-110$ & 54 & $522-8-3,20-50$ & 97 & $524-13-1,125-145$ \\
\hline 11 & $519-16-1,110-140$ & 55 & $522-25-2,75-110$ & 98 & $524-13-2,10-30$ \\
\hline 12 & $519-19-3,60-80$ & 56 & $522 \mathrm{~A}-2-2,50-60$ & 99 & $524-13-5,55-85$ \\
\hline 13 & $519-22-2,10-40$ & 57 & $522 \mathrm{~B}-1-6,90-105$ & 100 & $524-14-1,70-100$ \\
\hline 14 & $519-22-2,40-70$ & 58 & 522B-3-2, Piece 2A & 101 & $524-14-1,100-130$ \\
\hline 15 & $519-22-2,70-100$ & 59 & 522B-3-3, Piece 2A-B & 102 & $524-14-2,115-135$ \\
\hline 16 & $519-24-2,65-100$ & 60 & 522B-3-3, Piece $3 \mathrm{C}-4 \mathrm{~A}$ & 103 & $524-14-3,70-100$ \\
\hline 17 & $519-27-2,60-95$ & 61 & $522 \mathrm{~B}-5-1,0-25$ & 104 & $524-17-2,110-130$ \\
\hline 18 & 519A-8-1, Piece 1C & 62 & 522B-5-1, 105-125 & 105 & $524-17-2,130-150$ \\
\hline 19 & 519A-8-4, Piece 8 & 63 & 522B-5-1, Piece 8 & 106 & $524-17-3,0-20$ \\
\hline 20 & 519A-9-3, Piece 4 & $63 \mathrm{~A}$ & 522B-33, Piece 3C-4A & 107 & $524-17-3,100-125$ \\
\hline 21 & 519A-9-4, Piece 3H-J & 64 & $523-7, \mathrm{CC}, 0-15$ & 108 & $524-17-3,125-150$ \\
\hline 22 & $520-15-2,10-45$ & 65 & $523-32-1,65-85$ & 109 & $524-17-4,100-125$ \\
\hline 23 & $520-15-2,25-35$ & 66 & $523-32-1,85-105$ & 110 & $524-19-1,35-50$ \\
\hline 24 & $520-15-2,45-80$ & 67 & $523-37-3,35-75$ & 111 & $524-19-4,65-90$ \\
\hline 25 & $520-16-1,120-130$ & 68 & $523-43-1,35-70$ & 112 & $524-20-1,70-80$ \\
\hline 26 & $520-16-2,75-100$ & 69 & $523-47-1,120-135$ & 113 & $524-20-2,0-30$ \\
\hline 27 & $520-16-2,100-125$ & 70 & $524-4-1,0-25$ & 114 & $524-20-2,30-60$ \\
\hline 28 & $520-16-4,5-30$ & 71 & $524-4-1,10-20$ & 115 & $524-20-2,60-90$ \\
\hline 29 & $520-17-2,25-50$ & 72 & $524-4-1,25-50$ & 116 & $524-20-2,90-120$ \\
\hline 30 & $520-24-1,30-60$ & 73 & $524-4-1,28-34$ & 117 & $524-20-2,120-150$ \\
\hline 31 & $520-24-2,0-30$ & 74 & $524-4-3,35-65$ & 118 & $524-20-3,0-30$ \\
\hline 32 & $520-24-2,120-150$ & 75 & $524-4-4,0-25$ & 119 & $524-20-3,30-60$ \\
\hline 33 & $520-24-3,15-35$ & 76 & $524-6-2,110-135$ & 120 & $524-20-3,60-90$ \\
\hline 34 & $520-25-1,60-80$ & 77 & $524-6-3,47-53$ & 121 & $524-20-3,90-120$ \\
\hline 35 & $520-26-1,25-50$ & 78 & $524-6-3,110-150$ & 122 & $524-20-3,95-110$ \\
\hline 36 & $520-26-1,50-75$ & 79 & $524-7-1,45-65$ & 123 & $524-20-3,120-150$ \\
\hline 37 & $520-26-1,75-100$ & 80 & $524-7-2,10-20$ & 124 & $524-21-4,115-125$ \\
\hline 38 & $520-26-1,100-125$ & 81 & $524-7-2,55-70$ & 125 & $524-22-4,105-140$ \\
\hline 39 & $520-26-1,125-150$ & 82 & $524-7-4,60-85$ & 126 & $524-22-5,40-55$ \\
\hline 40 & $520-29-1,0-30$ & 83 & $524-8-1,15-30$ & 127 & $524-25-4,35-70$ \\
\hline 41 & $520-29-1,30-60$ & 84 & $524-8-4,15-25$ & 128 & $524-27-1,90-100$ \\
\hline 42 & $520-29-1,60-90$ & 85 & $524-8-4,75-85$ & 129 & $524-27-2,5-30$ \\
\hline 43 & $520-29-1,90-120$ & 86 & $524-9-3,135-150$ & 130 & $524-32-1,0-30$ \\
\hline 44 & $520-29-1,120-150$ & $86 \mathrm{~A}$ & $524-9-4,80-85$ & 131 & $524-32-1,30-60$ \\
\hline 45 & $520-29-2,0-30$ & 87 & $524-9-5,5-20$ & & \\
\hline
\end{tabular}

